\title{
France: 2004 Article IV Consultation-Staff Report; Staff Supplement; and Public Information Notice on the Executive Board Discussion
}

Under Article IV of the IMF's Articles of Agreement, the IMF holds bilateral discussions with members, usually every year. In the context of the 2004 Article IV consultation with France, the following documents have been released and are included in this package:

- the staff report for the 2004 Article IV consultation, prepared by a staff team of the IMF, following discussions that ended on July 6, 2004, with the officials of France on economic developments and policies. Based on information available at the time of these discussions, the staff report was completed on September 21, 2004. The views expressed in the staff report are those of the staff team and do not necessarily reflect the views of the Executive Board of the IMF.

- $\quad$ a staff supplement of October 15, 2004 updating information on recent developments.

- $\quad$ a Public Information Notice (PIN) summarizing the views of the Executive Board as expressed during its October 20, 2004 discussion of the staff report that concluded the Article IV consultation.

The documents listed below have been or will be separately released.

Financial System Stability Assessment

Report on the Observance of Standards and Codes-Fiscal Transparency and Data Module - Updates

Selected Issues Paper

The policy of publication of staff reports and other documents allows for the deletion of market-sensitive information.

To assist the IMF in evaluating the publication policy, reader comments are invited and may be sent by e-mail to publicationpolicy@imf.org.

Copies of this report are available to the public from

International Monetary Fund • Publication Services

$70019^{\text {th }}$ Street, N.W. • Washington, D.C. 20431

Telephone: (202) 623-7430 • Telefax: (202) 623-7201

E-mail: publications@imf.org •Internet: http://www.imf.org

Price: $\$ 15.00$ a copy

International Monetary Fund

Washington, D.C. 



\title{
INTERNATIONAL MONETARY FUND
}

\author{
FRANCE
}

\section{Staff Report for the 2004 Article IV Consultation}

Prepared by Staff Representatives for the 2004 Consultation with France

Approved by Michael Deppler and John Hicklin

September 21, 2004

The discussions took place in Paris during June 24-July 6, 2004. The teamMessrs. Leipold (Head), Everaert, Nadal De Simone, and Schule, Mmes. Allard and Giuliano (all EUR), and Mr. Ugolini (MFD) — met with Mr. Sarkozy, Minister of Economy, Finance, and Industry, Mr. Bussereau, Minister of the Budget, and their staff; Governor Noyer and officials of the Banque de France; Mr. Loos, Deputy Minister of Foreign Trade; economic advisors to the Prime Minister; the presidents of the finance commissions of the National Assembly and the Senate; officials of the ministries of health and social affairs, labor, and solidarity, the national statistics institute, the Banking Commission, as well as securities and insurance supervisors; and market participants, academics, and representatives of the employers' federation and labor unions. Seminars were held on drafts of two of the staff's Selected Issues Papers. Mr. Duquesne (Executive Director) or Mr. Cuny (Alternate Executive Director) attended the meetings.

The centre-right government is embarking on the second half of its five-year mandate with general and presidential elections due in 2007.

A Financial System Stability Assessment report was prepared as part of the Financial Sector Assessment Program (FSAP), the findings of which were discussed with the authorities during the mission.

France is an Article VIII member and, apart from certain security restrictions, maintains an exchange system free of restrictions (Appendix I).

France subscribes to the Fund's Special Data Dissemination Standard, and comprehensive economic data are available on a timely basis (Appendix II).

Updates of the Data Module and the Fiscal Transparency Module of the Reports on the Observance of Standards and Codes are being issued concurrently with this report. 


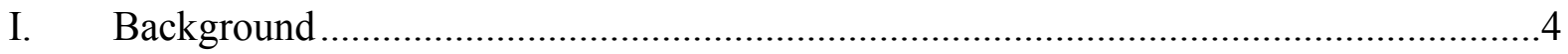

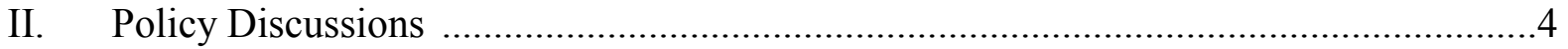

A. Economic Performance and Near-Term Outlook and Policies ............................6

B. Fiscal Consolidation Strategy ....................................................................... 15

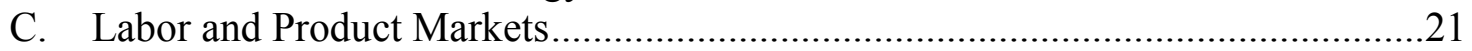

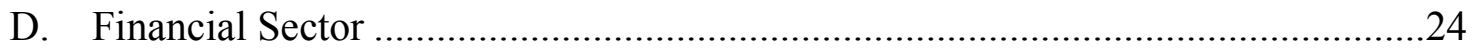

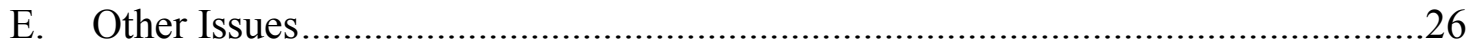

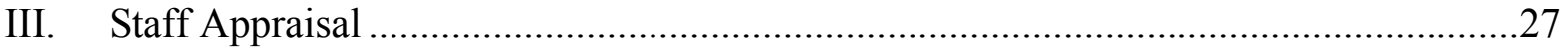

Figures

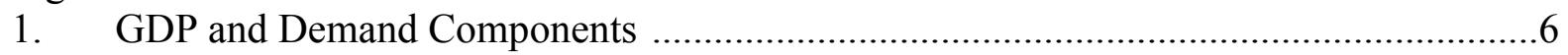

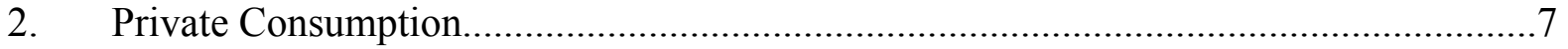

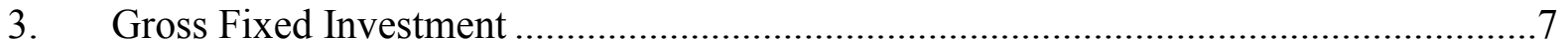

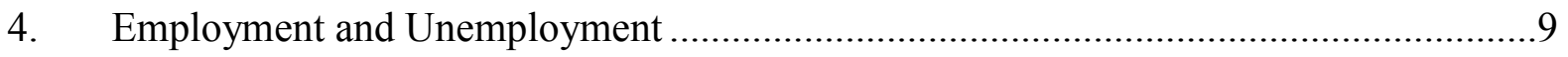

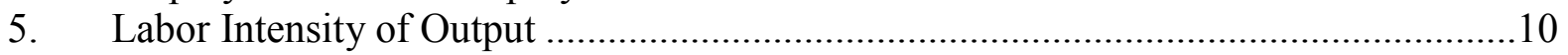

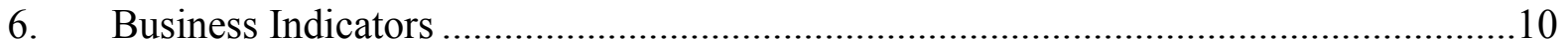

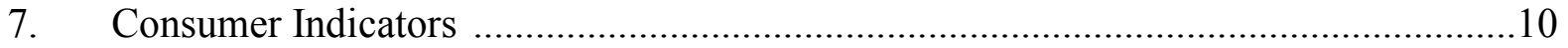

8. Real Effective Exchange Rates and Export Shares .............................................11

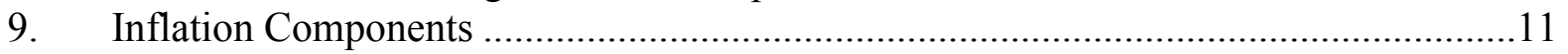

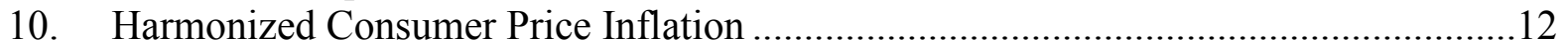

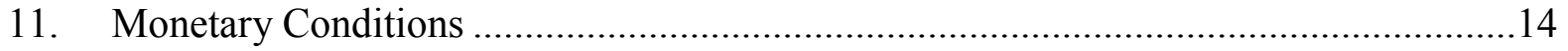

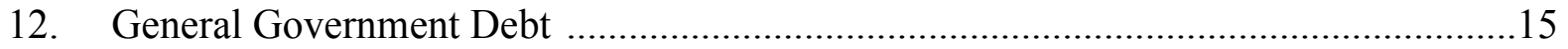

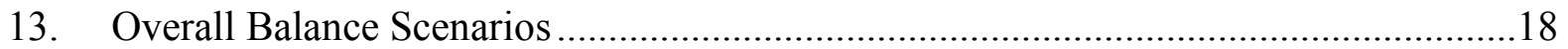

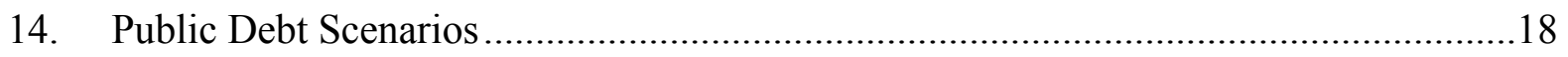

15. (De-)Regulation of Labor and Product Markets .....................................................22

\section{Tables}

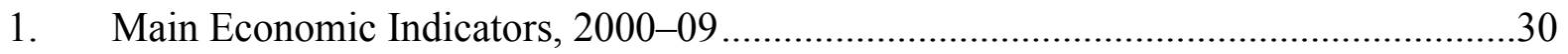

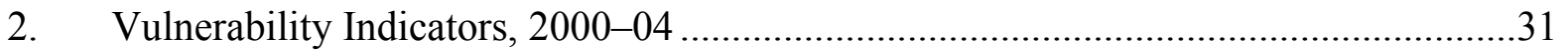

3. Public Sector Debt Sustainability Framework, 1999-2009 ......................................32

4. General Government Accounts 1996-2003 ...............................................................33

\section{Text Boxes}

1. Past Fund Policy Recommendations and Implementation ........................................5

2. Household Consumption: is its Recent Strength Enduring? ........................................

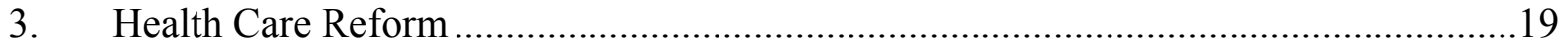

4. Youth Unemployment, Job Mobility, and Wage Growth .......................................23

5. FSAP Main Policy Recommendations ..............................................................25

Appendices

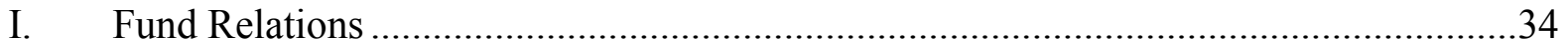

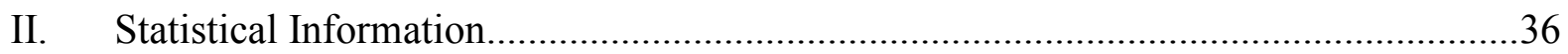




\section{Executive Summary}

The recovery is well under way with domestic demand as key driver and downside risks centered on external factors. Crucial reforms have been proceeding (notably of pension and health care systems), but changes in labor market institutions and work incentives have been harder to come by, held back by "social cohesion" concerns. In the staff's view, such changes need to be an integral part of the authorities' stated emphasis on growth-enhancing reforms if these are to succeed in securing fiscal sustainability. Until such reforms are in hand, direct expenditure restraint should aim at achieving a small structural surplus by the end of the decade. The Financial System Stability Assessment found no systemic risks. It urged a further strengthening of supervision and the phasing-out of state interventions in financial markets.

The strength of the current recovery has surprised, removing any cyclical concerns about proceeding with much-needed fiscal adjustment. There was consensus that GDP growth would average about 2.5 percent per year in 2004 and 2005. The authorities emphasized the need to sustain confidence in the recovery, in part by supporting incomes at the lower end of the income distribution and adopting a measured approach to fiscal adjustment. With the upswing in domestic demand sufficiently well-established and downside risks mainly from the external side, staff saw no need for supportive measures and room for greater structural fiscal adjustment.

Long-term growth is being fettered by structural weaknesses and adverse demographics, requiring comprehensive structural reforms. While progress is being made in several areas, labor market reform has reached an impasse. Reliance on budgetary measures to promote higher labor utilization stands in direct conflict with fiscal consolidation objectives. Meanwhile, the needed fundamental rethinking of labor market institutions has been left to reluctant social partners and entitlement reform is largely off limits.

The authorities intend to reduce the fiscal deficit to under 3 percent of GDP in 2005 and to rely on growth-enhancing reforms for long-term fiscal sustainability. Under current growth prospects, the overall deficit is likely to fall to less than 3 percent of GDP in 2005. The underlying structural adjustment implied by the official target is thus small while the pace of medium-term consolidation is unclear. In the staff's view, while pension and health care reforms have been beneficial, there is a need to step up reforms of employment protection and benefits to meaningfully increase labor utilization while securing structural fiscal adjustment. Until such reforms are in hand, direct expenditure restraint should aim at achieving a small structural surplus by the end of this decade before higher costs of aging kick in. The fiscal framework should be strengthened and automatic stabilizers should be allowed full play, in contrast to a new fiscal rule currently under consideration.

Ongoing product market deregulation, including simplification of administrative procedures, liberalization of network industries, and an acceleration of divestiture has raised the potential returns to increased labor market flexibility and growth prospects. The financial system was found to be resilient, but continued vigilance with respect to banks' risk exposure and further strengthening of supervision and phasing out of state intervention in financial markets were deemed necessary. The staff urged France to associate itself fully with efforts to bring the Doha round to a successful conclusion and welcomed the relatively high level of official development assistance (ODA). 


\section{BACKGROUND}

1. The cyclical recovery is well under way, but structural weaknesses and adverse demographics inhibit long-term growth. Triggered by foreign demand in mid-2003, the rebound in activity is now firmly led by private domestic spending, reflecting, inter alia, supportive policy conditions and the unwinding of a household savings overhang. Beyond the cyclical recovery, growth is impeded by structural factors, such as a high tax burden, adverse demographics, and low productivity growth. Moreover, fiscal sustainability is not yet secured, owing to a high structural deficit, rising dependency ratios, and increasing public spending on health care and labor market policies.

\section{Policies have had mixed results in achieving the intertwined objectives of fiscal} sustainability and higher long-term growth, in part owing to concerns about social cohesion (Box 1). Key reforms of the pension and health care systems have been tackled and steady advances are being made in product markets. However, rigid labor markets stand in the way of reaping full benefits from the latter and prevent higher labor utilization from translating into fiscal consolidation. Indeed, measures to promote labor supply and demandwhile having contributed to a positive record on employment - are weighing heavily on the budget. This is particularly the case for those measures taken to mitigate the adverse consequences on labor costs and supply of the implementation of the reduction in the workweek. The gradual approach to reform reflects a tension between widely held recognition of the need for change and equally widely spread concern that the associated retreat of the state would place low- and middle-income citizens at a disadvantage. This tension was evident in discussions of the mission with social partners, with labor unions indicating that reforms (and the adoption of Fund advice) would raise social exclusion and inequity, and employers noting that high labor costs and regulatory burdens put them at a competitive disadvantage.

\section{Policy Discussions}

3. The discussions focused on the outlook and where to strike the balance between up-front fiscal adjustment and structural reforms in the pursuit of fiscal sustainability. With the authorities perceiving confidence as still fragile, they favored a strategy of continued support to consumers, measured fiscal adjustment, and selected labor and product market reforms. For fiscal sustainability, they emphasized growth-enhancing structural reforms with moderate up-front consolidation. The staff saw a need for deeper reforms, especially in the labor market. ${ }^{1}$ As such reforms were not in the offing, it argued for a heightened focus on fiscal adjustment.

\footnotetext{
${ }^{1}$ The mission provided its views to a commission chaired by Mr. Camdessus and charged with identifying the structural impediments to growth in France.
} 


\section{Box 1. Past Fund Policy Recommendations and Implementation}

Successive governments have concurred broadly with the direction of the Fund's economic policy advice but have underscored the importance of social cohesion, expressed in generous welfare arrangements and a narrow income distribution. Policies have been marked by the tension between this focus and the concomitant quest for fiscal discipline and higher long-term growth, resulting in a gradual approach to reform. The dialogue with staff on these issues has been traditionally open and frank.

Fiscal policy: The Fund's long-standing advice to consolidate at an annual average pace of 0.5 percent of GDP until structural balance or surplus is achieved was not followed during 2000-03. Tax cuts induced by an overestimation of the strength of structural revenues and expenditure overruns increased the structural deficit. In line with Fund advice, pension reform has appreciably diminished the projected cost of aging and health care reform is making inroads, but civil service reform is yet to start in earnest. The authorities do not see room for sizeable expenditure cuts that would permit a much-needed early reduction in the tax burden.

Labor and product markets: The Fund has called for increasing flexibility in labor markets, especially in the context of the reduction of the workweek to 35 hours. The attendant increase in labor costs is being mitigated by cuts in social security contributions and improved labor organization, allowing more people to find jobs, but the overall net effect on potential output is negative while the costs to the budget are high. In line with Fund advice, additional flexibility was introduced, especially for smaller firms. Reform of labor market institutions and entitlements (other than pensions) remains to be tackled. In product markets, divestiture and deregulation are ongoing, albeit at a slower pace than advised by the Fund.

Financial sector: In line with Fund advice, the financial sector has been subject to strong supervision. The authorities have been reluctant to phase out widespread administrative interventions in financial markets, but some saving schemes have become more marketoriented.

Trade policy: The Fund has called on France to help advance trade liberalization, partly through a reform of the Common Agricultural Policy (CAP). Though the authorities agree in principle, and CAP reform is to be implemented in 2007, they have publicly voiced strong reservations about recent proposals, which they see as unbalanced. 


\section{A. Economic Performance and Near-Term Outlook and Policies}

4. Domestic demand has become the engine of growth. Following a weak first half of 2003 marred by geopolitical uncertainties, rising unemployment, faltering income growth, sticky downward adjustment of domestic retail interest rates and low overall confidence, a rebound in exports in mid-2003 initiated the current cyclical upturn (Figure 1 and Table 1). The subsequent strength of domestic demand, also in comparison to other major euro-area countries, was seen to owe much to the favorable starting point of the French economy: household savings were atypically high; the financial sector was very profitable; corporate balance sheet difficulties were confined to a limited number of large companies; and the housing sector was relatively robust (Table 2). ${ }^{2}$ Moreover - a point that the authorities emphasized-policies had been geared to inspire confidence. Pension reform had preserved the level of benefits, albeit at the expense of working longer; minimum wage increases had boosted income of the cash-constrained; the Figure 1. GDP and Demand Components suspension of a tax on productive assets for

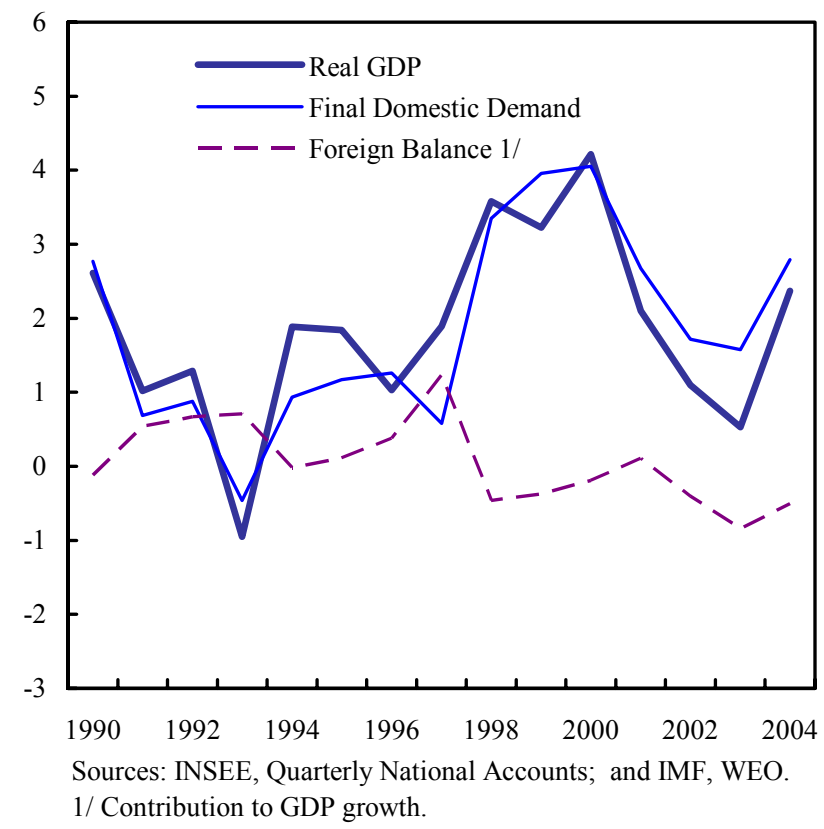
new investments (the taxe professionnelle) helped investor confidence; and several minor fiscal measures taken in 2004 supported household consumption (e.g., an interest deduction for consumer credits, a suspension of a tax on wealth transfers to the younger generation, and an agreement with the distribution sector to decrease prices on brand name products to break higher-than-actual inflation perceptions). ${ }^{3}$ In the authorities' view, these policies had paid off in the form of a relatively early and robust recovery compared to other large euro-area economies.

\section{The strength of private consumption was seen as reflecting both fundamental} and exceptional factors (Figure 2 and Box 2). During the initial phases of the downturn, household saving had, somewhat paradoxically, continued to rise, despite a decline in real

\footnotetext{
${ }^{2}$ This last element is a key difference with Germany where real house prices have been declining and the construction sector remains very weak.

${ }^{3}$ Large retailers can exert some monopoly power owing to legislation regarding distribution margins, which is being reconsidered (see $\mid 26$ ).
} 
disposable income as a result of job losses, moderate wage increases, lower nonwage income, and higher energy and food prices. There was consensus that wealth effects were weak in France while higher-than-actual price perceptions and low confidence had delayed spending. Consequently, when the economy turned, this backlog of consumption began to unwind. Declining real interest rates also buttressed the rise in the propensity to consume. The authorities stressed that exceptional factors - subnormal temperatures, extended sales, and higher outof-pocket medical expenses-boosted household consumption in the first quarter of 2004 and saw a need to sustain it, while staff saw somewhat greater underlying strength, subsequently confirmed by second quarter data.

6. Fixed investment is benefiting from a catch-up. As noted at the time of the 2003 Article IV Consultation, business investment had been weaker than expected during the downturn, with replacement investment being postponed (Figure 3). Partly because of accounting scandals, which had raised perceptions of heightened balance-sheet risk, companies were strengthening selffinancing capacity, prompting widespread deleveraging. With presently healthier balance sheets, improved demand prospects, and equity markets well off their post-bubble lows, corporate investment is rebounding strongly. Residential construction has moved up, reflecting several years of sustained real house price increases and low interest rates.

Figure 2. Private Consumption

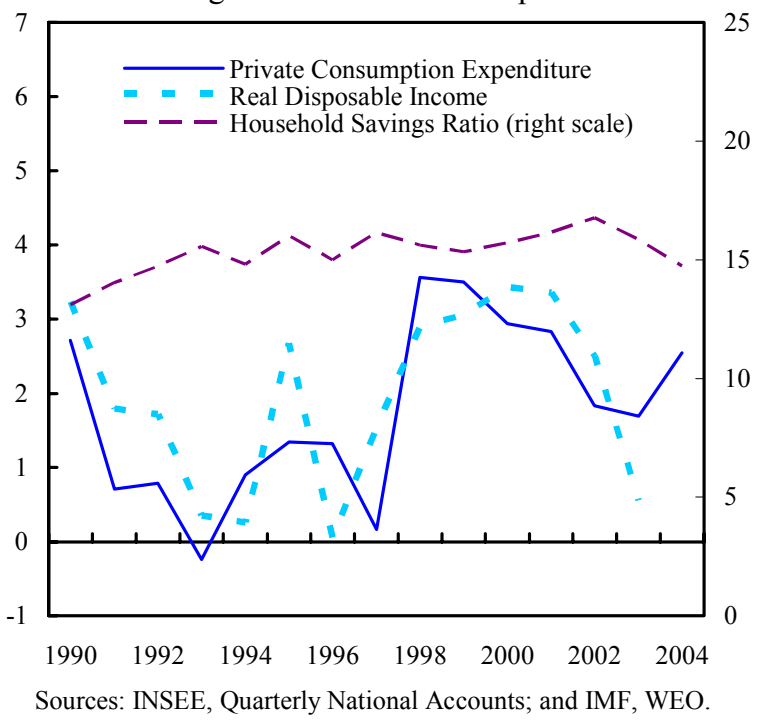

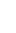

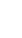




\section{Box 2: Household Consumption: is its Recent Strength Enduring?}

Following a sharp increase during the 1990s and the initial phase of the recent cyclical downturn, the conventionally-measured household savings rate has dropped sharply since mid-2003, raising the question of the sustainability of the rebound in private consumption.

Perceptions of stronger-than-reported inflation, uncertainties surrounding social security reforms, and poor employment prospects appear to have restrained spending through most of 2003. These factors opened a gap between long-term equilibrium and actual consumption. The first one, as reported in surveys, has been attributed to sharp price increases in some highly visible consumption goods and services after the introduction of euro notes and coins. With the wedge between measured and perceived inflation no longer widening, pension and health care reforms clarified, and economic recovery under way, the current strength of household consumption (abstracting from the exceptional factors in early 2004) is not too surprising. In addition, income support and wage increases at the bottom of the income distribution are likely to have temporarily elevated the propensity to consume.

Moreover, equilibrium consumption may well be lower than it could be because of incomplete financial markets which limit the possibility of converting gains in nonfinancial wealth into liquidity. Indeed, the secular increase of French household savings in the 1990s contrasts sharply with the observed decline in other countries, attributed to gains in wealth of which France also benefited.

Staff analysis, using aggregate time series econometrics, confirms that consumption (of nondurables) tracks real disposable income closely in France, but that wealth effects matter as well (see Selected Issues paper). The latter are, however, smaller than in the United States, and the impact of nonfinancial assets (housing) remains uncertain. These results are compatible with strong risk aversion of households and incomplete financial markets. Consequently, while the outlook for consumption remains bright, there is also a role for policies to improve the working of consumer and mortgage credit markets and strengthen confidence through growth-oriented structural reforms. 
Figure 4. France: Employment and Unemployment
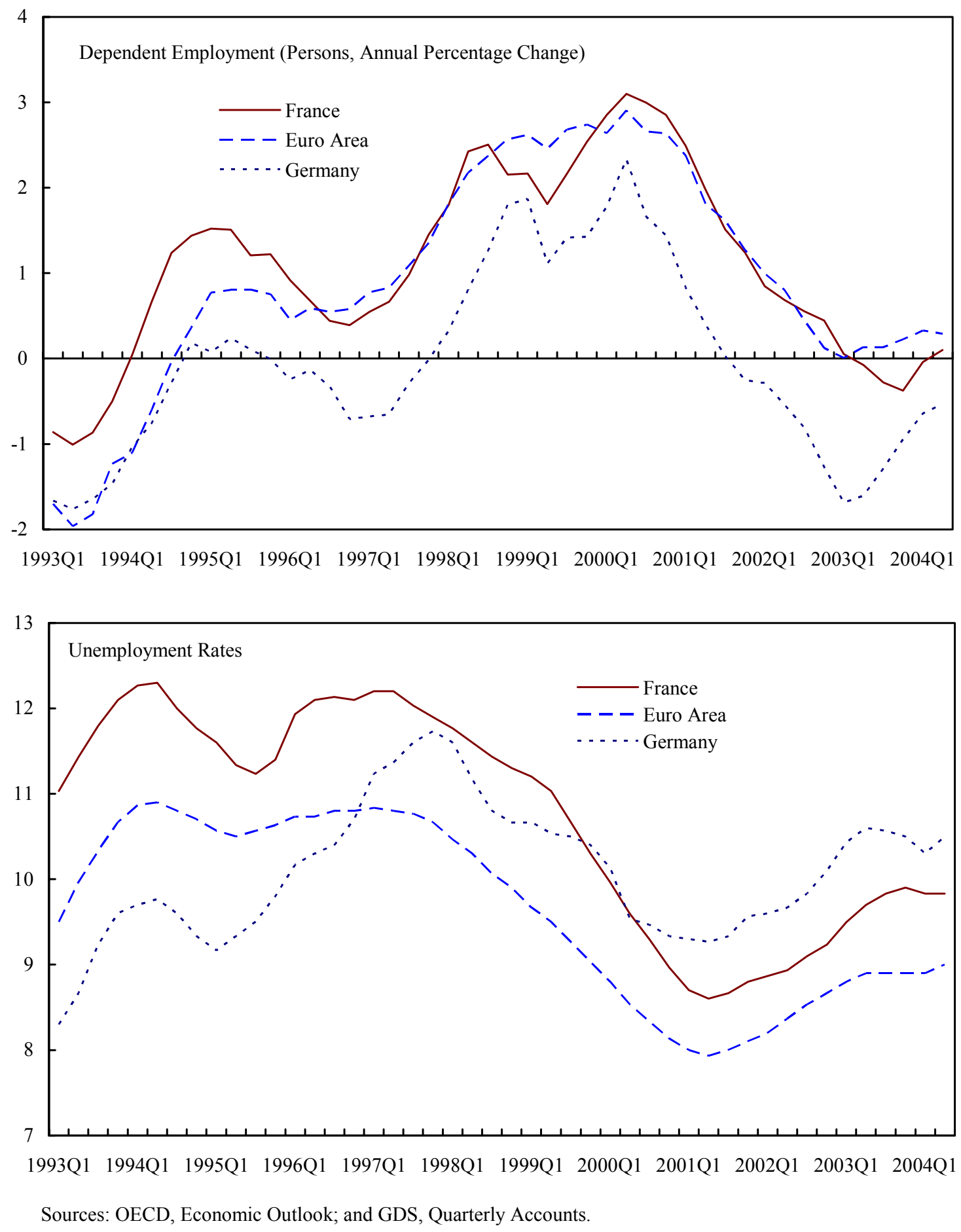
Conversely, labor hoarding and wage moderation contributed to a higher labor intensity of output, particularly during the initial phase of the downswing (Figure 5). Targeted cuts in social security contributions helped sustain employment, resulting in a substitution of low-skilled labor for capital and high-skilled workers, and in a slowdown in measured labor productivity growth. Consequently, unemployment increased less rapidly than in the past, helped also by diminishing labor supply growth owing to demographics and early retirements.

\section{There was agreement that the recovery was well} under way with downside risks centered on external factors. The authorities concurred that growth would be close to 2.5 percent in 2004, significantly higher than the 1.7 percent underlying the 2004 budget - but new official forecasts will not be available until the fall. Risks to the outlook seemed balanced between external factors on the downside (oil prices, the euro, and demand in the rest of the euro area) and domestic factors on the upside (mainly private consumption). It was noted that the direct effect of higher oil prices would be dampened somewhat by France's high reliance on nuclear power, but that indirect effects through slower partner country growth could be significant. Similarly, further euro appreciation and weaker-than-envisaged domestic demand in Germany and Italy could adversely affect growth. On the other hand, house prices were not considered a key risk as their wealth effects were small (Box 2); recent price increases were seen to be largely driven by fundamentals; and household indebtedness was low by international standards. In addition, with household savings still high, private consumption could surprise on the upside, especially if employment prospects improved more rapidly. Since the mission, some elements of both upand downside risks have materialized: domestic demand has been stronger than expected, while oil prices have been much higher. The staff projects GDP growth of 2.6 percent in 2004, in line with confidence indicators (Figures 6 and 7) and 2.3 percent in 2005.
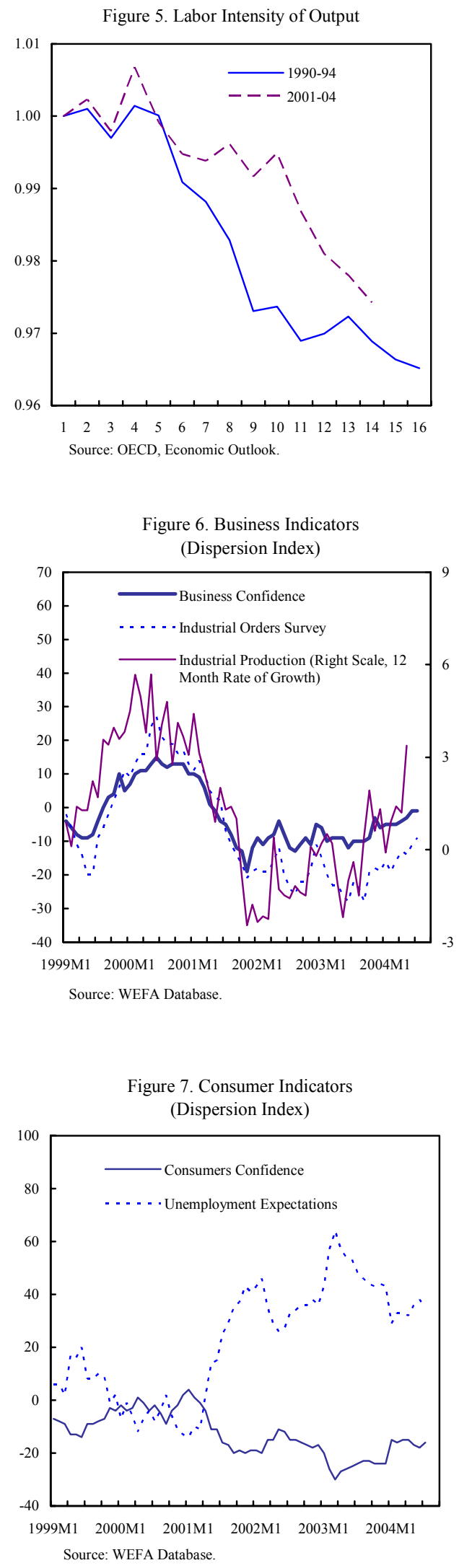
9. The current account surplus is projected to turn into deficit in the near term, partly for cyclical reasons. There was consensus that the cumulated effect of euro appreciation, though not of major concern, had been leaving its mark on the external accounts, especially via tourism. Export performance had recently been comparatively weak (Figure 8), owing to the real appreciation of the exchange rate vis-à-vis other EU countries and structural factors, in particular the pattern of regional trade (with the high weight of Germany where domestic demand remained weak) and product specialization (e.g., the airline industry, affected by geopolitical turmoil). In the near term, with domestic demand running ahead of that of major euro-area trading partners, the trade balance and current account are projected to move into a deficit.

\section{Inflation is expected to remain} persistent for some time. Headline inflation has continued to run well above 2 percent, buffeted by energy and service price rises and increases in regulated prices and indirect taxes (Figure 9). The authorities underscored that the latter had accounted for over one-third of overall inflation by early 2004, contributing to a large Frenchspecific inflation component (Figure 10). Some of these factors as well as low productivity gains and increases in minimum wages also explain the persistence of underlying inflation (at about 1.6 percent), despite the slack in the economy and past euro appreciation. Looking ahead, health care reforms were likely to sustain underlying inflation in the near term. In addition, higher-than-expected oil prices foreshadow higher headline inflation.

The staff nonetheless sees the latter retreating to less than 2 percent in the course of 2005 . As emphasized by the authorities, it will be important to avoid second-round effects from energy and regulated price hikes.
Figure 8. Real Effective Exchange Rates and Export Shares

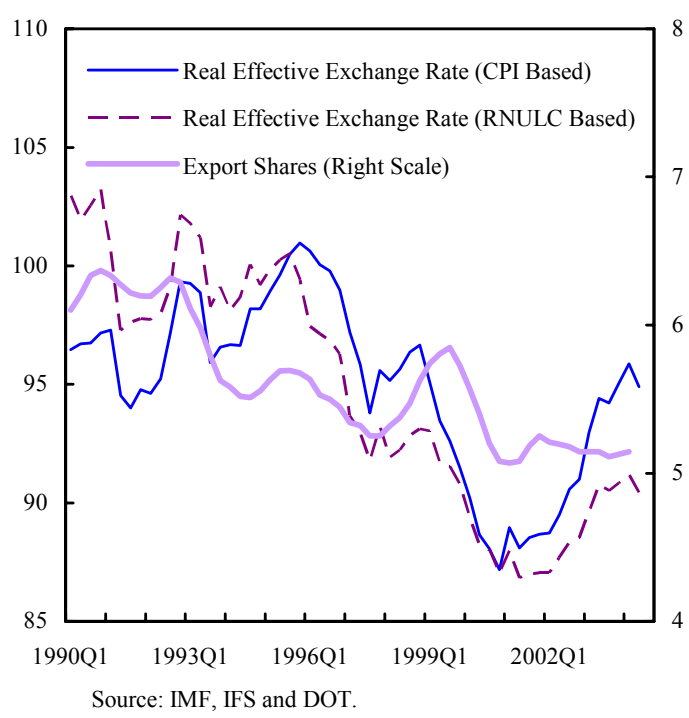

Figure 9. Inflation Components (Annual growth rates)

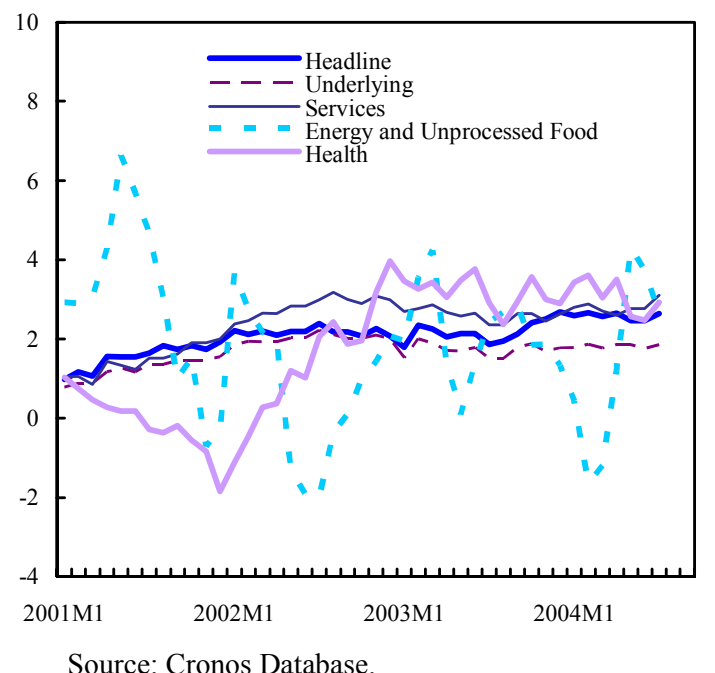

Source: Cronos Database. 
Figure 10. France: Harmonized Consumer Price Inflation 1/ (Annual percent change)
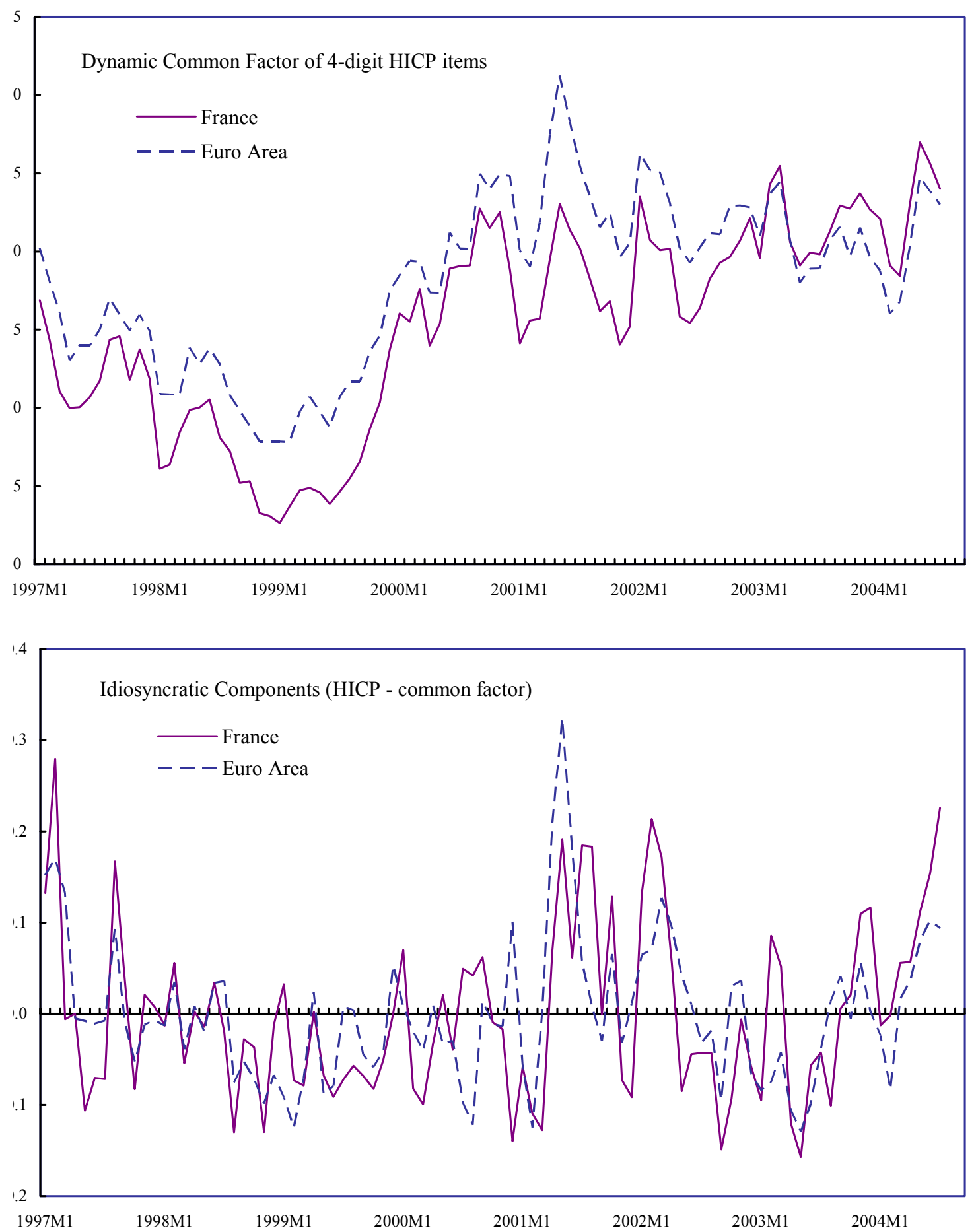

Sources: Cronos Database; and IMF staff estimates.

$1 /$ The common and idiosyncratic components are estimated using the generalized dynamic factor model proposed by Forni and others (2003), which uses the dynamic covariance structure of a panel of 12 euro-area HICP from January 1997 to July 2004. 
11. The authorities agreed that monetary conditions were supportive and that a closer link between administered and market interest rates would facilitate monetary transmission. The decline in real interest rates had offset most of the impact of the euro's appreciation (Figure 11). Short-term real interest rates were close to zero, and long-term rates appeared consistent with growth at potential rates. Nonetheless, the staff observed that domestic retail interest rates had adjusted very slowly to reductions in the ECB's policy rates, owing to administrative interventions in financial markets. Consequently, during the recent easing cycle, this sluggishness was estimated to have caused consumption to be lower by 1.7 percentage points compared to the counterfactual of immediate pass-through (see Selected Issues paper). It was agreed that the new interest rate adjustment mechanism in place since mid-2003 would strengthen the response of domestic interest rates, ${ }^{4}$ though the authorities recognized that it still did not render it instantaneous and did not apply to all administered rates. While generally disposed toward closer alignment of administered and market rates, the authorities were not inclined to phase out administered savings schemes in the near term, inter alia pointing to their use to finance social housing.

\section{With growth exceeding expectations, staff stressed that a resumption of fiscal} consolidation would not threaten the recovery. In 2003, against the weak economic environment, the fiscal stance had been supportive, as automatic stabilizers had been allowed to play fully, and no structural adjustment took place. As a result, the deficit widened from 3.3 percent of GDP in 2002 to 4.1 percent of GDP in 2003. For 2004-05, the fiscal stance was set to be moderately restrictive. The staff noted that the fiscal measures implemented in early 2004 to boost consumption seemed unnecessary, but agreed that they had been confidence-enhancing and would have virtually no impact on the budget.

\footnotetext{
${ }^{4}$ In mid-2003, some administered interest rates were adjusted downward toward prevailing market rates and a new formula adopted that would lead to their automatic six-monthly adjustment, though potentially only for half of the change, given the 50-percent weight of inflation, and with inflation as a floor.
} 
Figure 11. France: Monetary Conditions

(Using underlying CPI)
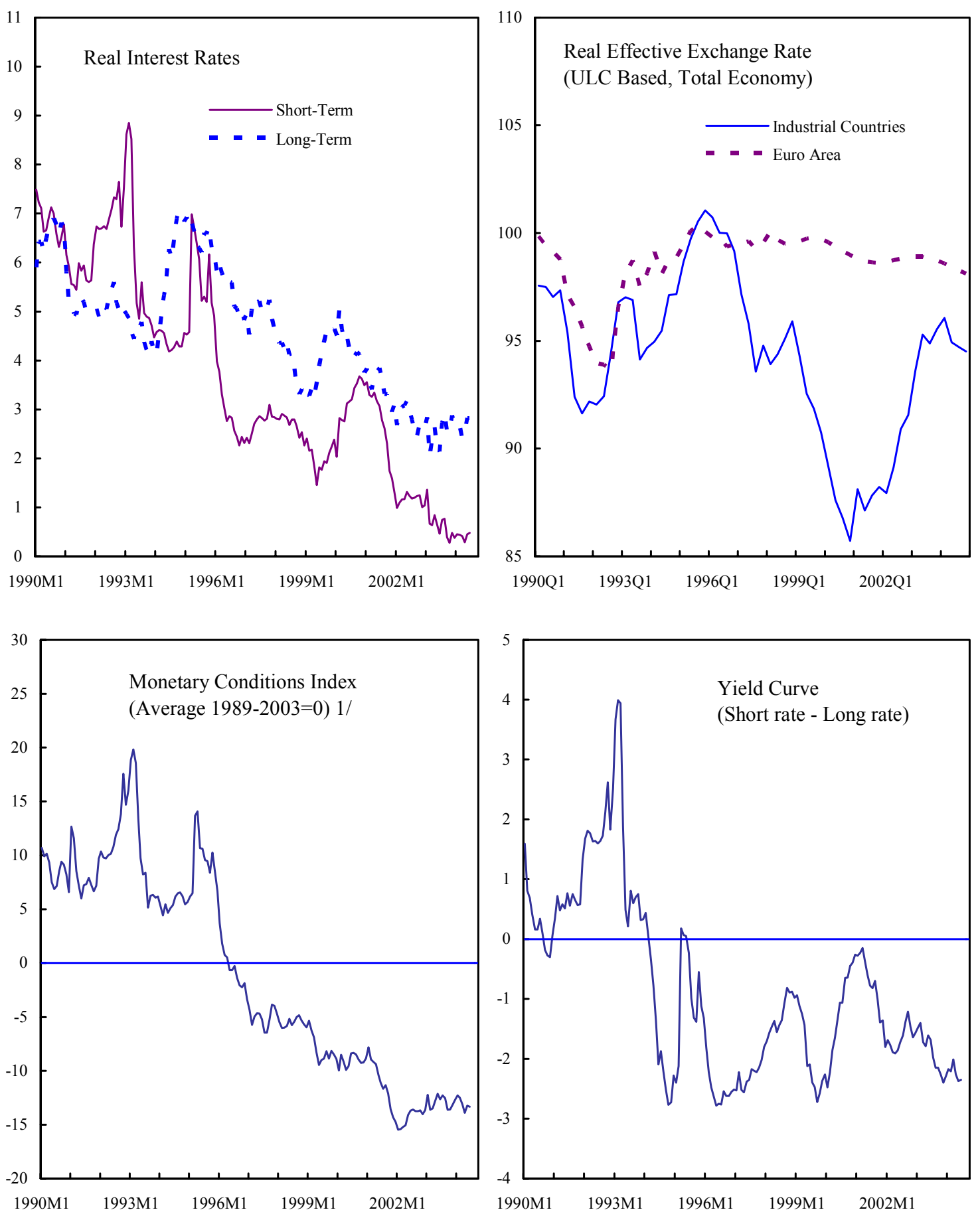

Sources: Datastream-Thomson Financial; Cronos database; and IMF, IFS.

$1 /$ The monetary conditions index is a weighted average of the real effective exchange rate and the short-term real interest rate, with weights, 1 and 2.5, respectively. A higher index implies tighter conditions. 


\section{B. Fiscal Consolidation Strategy}

13. Concerned with rising public debt, the authorities were keen to resume fiscal adjustment (Figure 12). They agreed that without adjustment, the debt ratio was vulnerable to significant increases over the next five years, especially if growth faltered, as brought out by the standard debt sustainability analysis (Table 3). While higher-than-anticipated growth could allow the nominal 2004 budget deficit objective to be achieved (3.4 percent of GDP), the envisaged structural adjustment will be lower than originally targeted ( 0.6 instead of some 0.8 percentage point of GDP). At the central government level, freezing credits and postponing some expenditure, as in 2003, will allow spending to respect nominal budget limits. But slippages continue in health care, and the delay in lowering the duration of unemployment benefits will also weigh on the budget. ${ }^{5}$ Nonetheless, spending is falling as a share of GDP, in part due to higher-than-projected inflation (Text Table 1). There was agreement that all revenue windfalls from higher nominal growth in 2004 should be fully saved. Furthermore, the authorities saw scope to reduce gross debt through divestiture and sold part of their stake in France Télécom in September.

\section{The authorities' principal near-term objectives are to reduce the overall deficit} to less than 3 percent of GDP in 2005 and to 2.5 percent of GDP in 2006, which on current projections implies only a modest structural adjustment. Though no final decisions had been made, the authorities generally agreed that there was no room for new tax cuts over this horizon. They also felt that it would be difficult to reach these budget objectives without higher-than-anticipated growth or the help of one-off factors, such as the transfer of pension funds from the public utilities. Keeping central government spending constant in real terms would not suffice to cover the start-up costs of health care reforms, while the reforms might not succeed in reducing the health system's deficit as much as planned ( $\mid 18)$. In the event, growth now looks stronger than envisaged, bringing the nominal targets within reach without other measures. However, achieving them would represent a cumulative structural adjustment of only about 0.5 percentage points of GDP over 2005-06. Consequently, the staff called for more ambitious consolidation ( $₫ 16)$. A supplement to this report covering the 2005 budget will revisit these issues.

\footnotetext{
${ }^{5}$ Starting in January 2004, social partners had agreed to reduce unemployment benefit duration on average by about 7 months, but the High Justice Court ruled that this measure could not apply to those that were unemployed at the time of the decision.
} 
Text Table 1: General Government - Current Policies

(In percent of GDP)

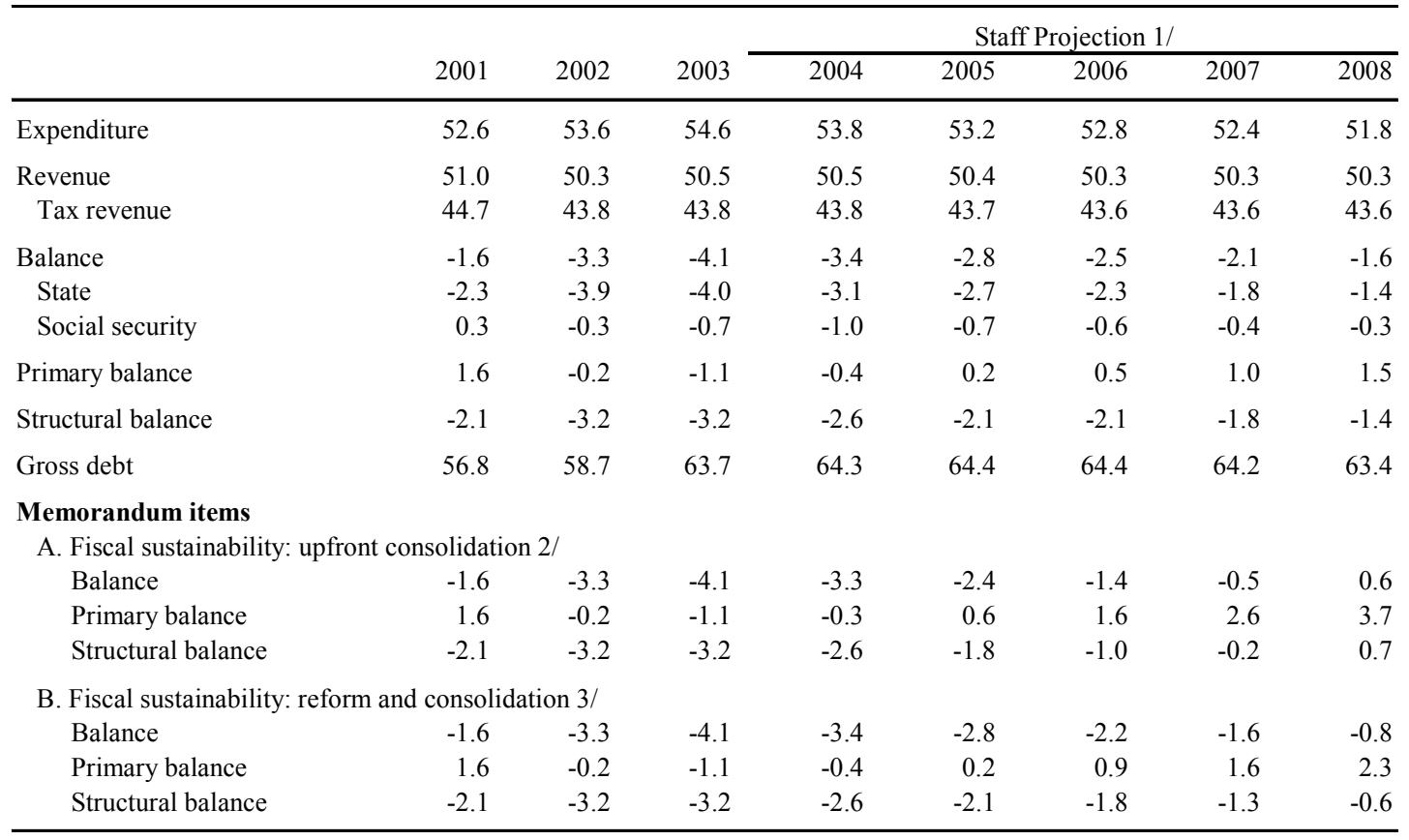

Sources: Data provided by the authorities; and IMF staff calculations.

1/ Staff projections are based on the authorities' 2004 budget, plans for freezing central government level spending, health care reform, and cuts in social security contributions, adjusted for the staff's macroeconomic assumptions and judgment on social security spending.

2/ Through upfront fiscal consolidation, this scenario allows growing pension spending over the next 50 years to be offset by lower interest payments due to the declining public debt burden. Sustainability is defined as the public debt-to-GDP ratio stabilizing at the same horizon as the dependency ratio.

3 / Same as in footnote 2 but with structural reforms raising the employment rate to 70 percent by 2010 . The public debt-to-GDP ratio stabilizes at a higher level, requiring less fiscal consolidation.

15. The emphasis of the authorities' long-run fiscal consolidation strategy appears to have shifted away from medium-term budget balance and toward growth-enhancing structural reforms. While the latest Stability Program update (December 2003) aimed for a near structural balance by 2007, in this year's preparatory document for the 2005 budget, the authorities argued that the fiscal consequences of aging should be dealt with mainly through reforms (about two-thirds), but less (the remaining one-third) through direct fiscal adjustment. Assuming successful pension and health care reform-which had been completed - and further to-be-identified structural reforms, the document presented as sustainable a scenario based on a long-term average structural deficit of about 1 percent of GDP. The authorities underscored that this however required a considerable adjustment from the present structural deficit, estimated at about 2.5-3.0 percent of GDP. In setting compliance targets under the Stability and Growth Pact, whose usefulness they stressed, they argued against a "one-size-fits-all approach" (represented by the close-to-balance rule) and in favor of taking into account country-specific circumstances, such as the initial level of public debt and the remaining unfunded costs of aging. 
16. The staff supported the emphasis on growth-enhancing structural reforms, but stressed that the current reform agenda would need to be strengthened appreciably to meet the challenge and that direct fiscal consolidation would also need to contribute. To illustrate the magnitude of the challenge, assuming that current structural reforms are on track to lower the NAIRU to 7 percent in the next 5 years ${ }^{6}$, fiscal sustainability through upfront adjustment would require an overall structural surplus of 0.7 percent of GDP by 2008 , 2.2 percentage points more than under current policies (Figures 13 and 14 and Text Table 1$).^{7}$ A decisive reform strategy that would raise the employment rate from 63.4 percent $^{8}$ in 2003 to 70 percent by 2010 , significantly reduces, but does not eliminate, the need for up-front fiscal adjustment. It requires lowering the structural deficit to about 0.5 percent of GDP by 2008, implying additional adjustment of 1 percentage point compared to current policies. ${ }^{9}$ Such an ambitious reform strategy, while highly desirable in the staff's view, is, however, not currently on the agenda. Consequently, until it is, the staff saw a need for sustained expenditure-based adjustment at a pace somewhat more than three-quarters of one percent of GDP per year until a small structural surplus is achieved. However, given the high tax burden, as future structural reforms are implemented and pay off in terms of higher long-term growth, further growth-enhancing tax cuts should be moved up on the agenda. Such a move could be considered when a small, enduring structural surplus is achieved.

\section{Progress on structural adjustment will require breaking the pernicious link} between the budget and labor market policies. The authorities had become well aware of the high budgetary cost of their active labor market policies (mostly cuts in social security contributions and to a lesser extent the earned income tax credit - together estimated to amount to 1 percent of GDP by 2005). These policies had been instituted to offset the adverse consequences on labor costs and employment of high and rising minimum wages, the mandatory 35-hour workweek, and high marginal tax and benefit replacement rates. This circle was set to take another vicious turn in 2005 with a large step increase in the minimum wage (SMIC) (3.8 percent in real terms), accompanied by partly offsetting cuts in social security contributions. ${ }^{10}$

\footnotetext{
${ }^{6}$ The staff estimates that effects of past wage moderation and ongoing reforms would suffice to achieve this objective.

${ }^{7}$ Fiscal sustainability is defined as a constant public debt-to-GDP ratio at the time the dependency ratio stabilizes and costs of aging no longer increase as a share of GDP.

${ }^{8}$ OECD data based on 15-64 age group.

${ }^{9}$ In this reform scenario general government real spending can grow at 0.8 percent per year during $2005-08$, compared to current plans of 1.3 percent per year. Without reforms, spending growth needs to be compressed to 0.2 percent per year.

${ }^{10}$ This increase is the last step in the harmonization of the multiple monthly minimum wages that emerged from the phased adoption of the 35-hour workweek.
} 
Figure 13. Overall Balance Scenarios

(In percent of GDP)

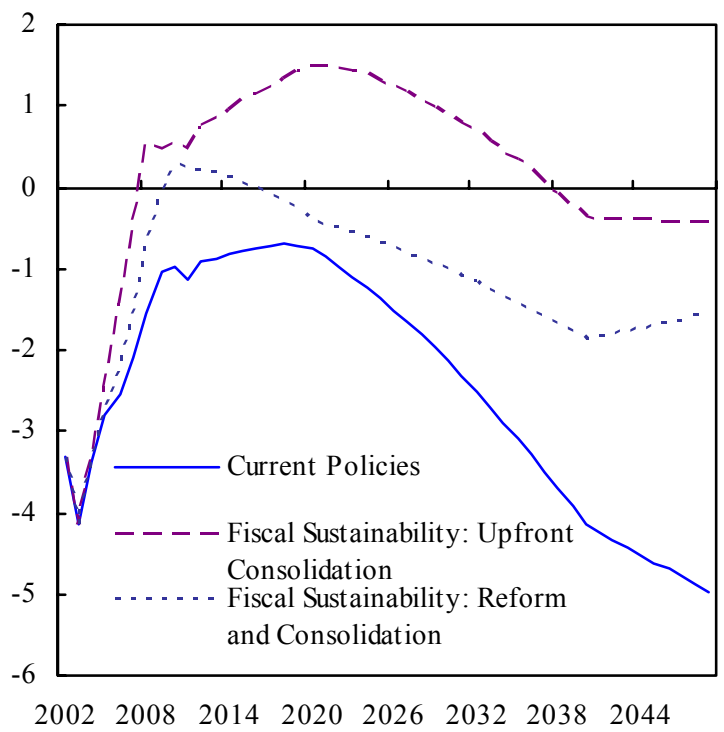

Sources: Data provided by the authorities; and IMF staff calculations.
Figure 14. Public Debt Scenarios

(In percent of GDP)

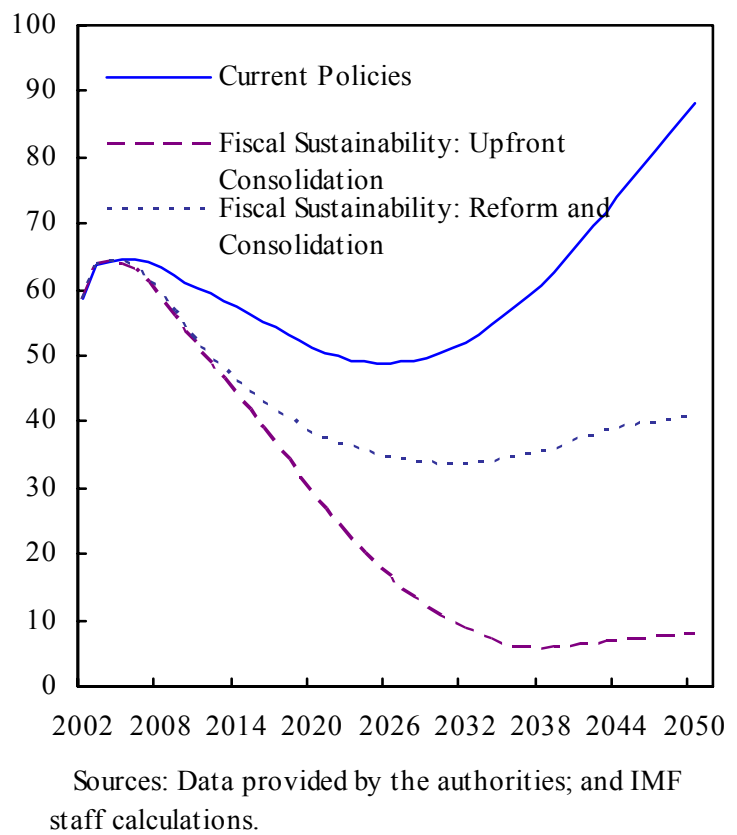

To mitigate the budgetary impact of these policies, the authorities were considering various options: (i) spreading the minimum wage increases over time; (ii) narrowing the salary range over which social security contributions are reduced (it currently reaches up to 1.7 times the $S M I C$ ); (iii) reducing the upper income limit of the earned income tax credit; and (iv) reforming the workweek restrictions and employment protection. ${ }^{11}$ However, at the same time, a new "social cohesion" plan had been announced at significant budgetary cost and with uncertain implications for labor market performance ( $\mid 25)$. The staff urged the authorities to fund this plan out of existing resources and to focus on reforming employment protection and entitlements, which would have large benefits in terms of employment and possibly positive effects on the budget.

\section{There was consensus that effective health care, pension and civil service reforms and well thought-out decentralization would be key avenues for fiscal consolidation:}

- Health care reform had been well designed but its ultimate effectiveness would depend on its implementation (Box 3). The reform establishes the instruments to gain control over the system's budget, by putting in place mechanisms that can adjust key

\footnotetext{
${ }^{11}$ Since the mission, option (i) was announced but then withdrawn, and option (ii) is now being pursued.
} 


\section{Box 3. Health Care Reform}

Total and public health care spending (three quarters of total) are relatively high in France, and public spending has been growing faster than targeted. Between 1997 and 2004 (March), it rose by 4.7 percent per year, compared to a norm of 3 percent and disposable income growth of 3.3 percent. Health care is generally perceived to be of high quality.

\section{The sources of spending pressure have} included widening coverage, increasing tariffs of consultations, escalating prices of pharmaceuticals, mounting personnel costs due to the workweek reduction, and rising service volumes related to technological progress and an increase in the share of population closer to death.

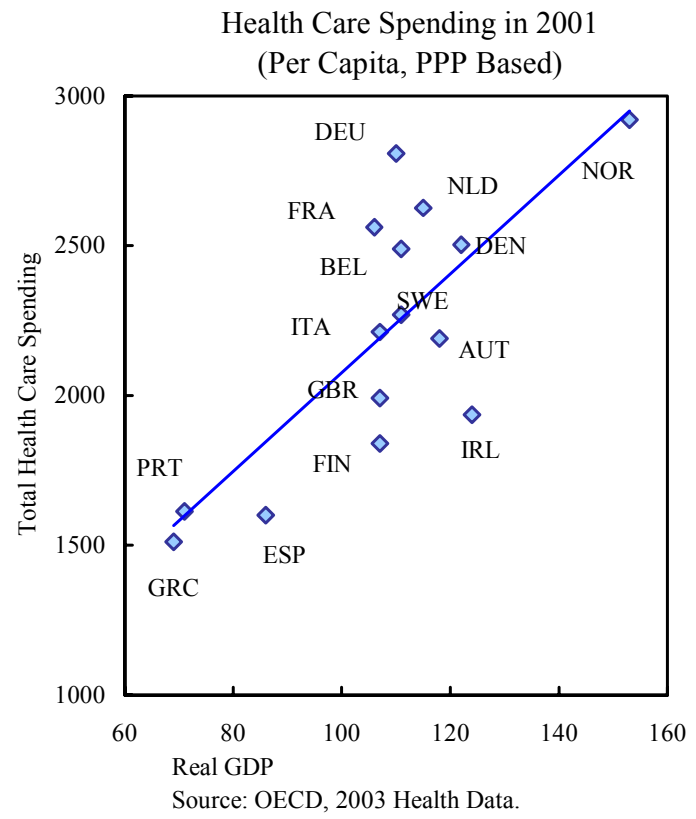

Health Care Spending in 2001

Source: OECD, 2003 Health Data.

Following several piecemeal measures, a

comprehensive health care reform was approved in mid-2004 with the aim of balancing the books by 2007, while increasing quality and preserving equal access. The reform introduces the possibility to modulate all key parameters governing the behavior of patients, medical professionals, and insurance agents. The initial values of the parameters chosen, together with measures taken to raise revenues, are officially estimated to yield budgetary savings of about $€ 15$ billion in 2007 , equivalent to the ministry of health's projection of the deficit before measures:

\begin{tabular}{|l|l|l|l|}
\hline \multicolumn{2}{|l|}{ Lower expenditure: (billions of euro) } & Higher revenues: (billions of euro) \\
\hline Medical cost control & 3.5 & Copayment $€ 1$ & 0.65 \\
\hline Pharmaceuticals & 2.5 & Enterprise tax (C3S) & 0.78 \\
\hline Hospital procurement & 1.5 & $\begin{array}{l}\text { Increase in social security contributions } \\
\text { of retirees; workers; financial services; } \\
\text { and lotteries (CSG) }\end{array}$ & 2.29 \\
\hline Control sick leave & 0.8 & Contribution of the state & 1.0 \\
\hline Improve administration & 0.5 & Increase of copayment hospital & 0.3 \\
\hline Cut financing costs & 1.0 & & 5.0 \\
\hline Total: & 9.8 & Total: & \\
\hline
\end{tabular}

The measures appear insufficient to eliminate the projected budget deficit, which itself may be underestimated. The impact of expenditure control measures is highly uncertain, transfers from the state do not lower the general government deficit, and the higher costs of operating an improved administration of the health care system have not been taken into account. Moreover, the system's trend deficit before measures is projected by the health insurance agency $(C N A M)$ to reach $€ 23$ billion by 2007 . 
parameters to influence behavior of patients, providers, and insurance agencies and the revenues of the system. Nonetheless, there was a general perception that the initial parameters chosen were too timid to ensure the stated objective of a return to balance of the health system's budget by 2007, though it was agreed that estimating the budgetary impact of measures designed to affect behaviors was difficult.

- The 1993 and 2003 pension reforms have brought the projected costs of aging in France to well below the euro-area average and established regular five-year reviews to secure the system's sustainability. ${ }^{12}$ While these reforms need to mature before considering further changes, the staff argued for phasing out early retirement schemes and reducing the generosity of some special retirement regimes, particularly when funded by the taxpayer.

- The nonreplacement of retiring civil servants had so far been used only symbolically, far short of the guideline that on average only one out of two positions should be retained. ${ }^{13}$ With personnel expenses topping 40 percent of the budget envelope (Table 4), the authorities agreed that more efforts were needed in this area, but political appetite was lacking.

- The authorities saw decentralization as an opportunity to better tailor public services to local needs and achieve efficiency gains, particularly in the areas of education, infrastructure, and social programs. Acknowledging the merits of such an approach, staff urged the authorities to allow sufficient fiscal autonomy and own resources to local governments so as to induce them to improve spending efficiency. To this end, staff suggested the introduction of a local surcharge on either the personal income tax or the general social security contribution $(C S G)$, but the authorities felt that implementation difficulties would offset potential gains.

19. The authorities were examining the scope for closing tax niches, but in the absence of room for tax cuts were reluctant to make wholesale changes to the tax structure. They nonetheless felt the need to remove the taxe professionnelle (TP) - a highly distortionary tax on capital that had been suspended in January 2004, initially for 18 months and now through end-2005- but found it difficult to identify workable alternatives. This tax is a major source of financing for local governments and is seen to establish a politically important link between industry location and local tax revenues. The staff argued that more reliance on charges and fees for services provided to enterprises, as well as households, should be considered. The mission's call for higher real estate taxes and the abolition of

\footnotetext{
${ }^{12}$ With pensions indexed to inflation, projected replacement rates are low. In addition, new private pension savings vehicles (e.g., PERP) were introduced in 2004.

${ }^{13}$ Of about 60,000 retiring civil servants in 2005 , only 8,000 are not to be replaced.
} 
preferential VAT rates ${ }^{14}$ to replace some of the $T P$ along with a local surcharge on income taxes were met with little enthusiasm.

20. The authorities recognized that preserving cyclical revenue windfalls would be key to fiscal consolidation, but their proposed rule fell short of full operation of automatic stabilizers. Mindful of previous episodes when cyclical windfalls had given rise to permanent tax cuts (e.g., the "cagnotte" episode in 2000), the authorities were seeking to enshrine in law a mechanism that would avoid such events. Their proposal would earmark at least (authorities' emphasis) two-thirds of higher-than-budgeted revenues for deficit reduction, and limit use of the remainder to temporary tax cuts or investment spending, and only in the year following the windfall. The staff advocated full play of automatic stabilizers and noted that the authorities' proposed rule was asymmetrical and procyclical, which in other countries (e.g., the Netherlands) had given rise to structural slippage. The authorities responded that the staff proposal left policy-makers with no room for maneuver and would not be politically enforceable. Their simulations showed that application of the rule even with permanent tax cuts or spending increases would lead to a structural budget deterioration over a typical cycle of only about 0.1 percentage point of GDP per year. Moreover, they stressed that no windfalls would be spent in 2004 and, more generally, until the deficit fell below an acceptable threshold. The staff welcomed this intention-which it felt would need to be adhered to well beyond 2004 — and questioned the political feasibility of "temporary" tax cuts or spending increases as envisaged under the authorities' proposed rule.

\section{Other measures were under way or under consideration to strengthen the fiscal} framework. The new budget law would be fully applied in 2006 requiring zero-base budgeting and multi-year programming for spending agents. The preparation of its implementation was already improving spending control at the central government level, including through early interministerial coordination. The budget law would also promote using spending ceilings in terms of levels. A multiyear budgeting approach for social security and an internal stability pact with local authorities are under consideration. The authorities saw merit in the staff proposal to establish an independent agency to conduct forwardlooking budget assessments. The staff also called for a higher frequency of publication of government accounts, including by sub-levels, to improve transparency and accountability.

\section{Labor and Product Markets}

22. There was agreement that labor and product market reforms were needed to lift potential growth prospects. Key weaknesses lie in low participation and employment rates and declining numbers of hours worked. Moreover, adverse demographics would soon reduce the labor force, and total factor productivity growth had declined, though this was seen as a likely transitory phenomenon while low-productivity workers were being absorbed

\footnotetext{
${ }^{14}$ The base for real estate taxes has not kept up with increases in house prices and the use of preferential VAT rates is an inefficient way of achieving social objectives (see "Tax Reform and Potential Growth in France", in Country Report 03/335).
} 
in the labor force. High minimum wages were pricing the low-skilled out of employment, and high replacement income reduced labor supply, both requiring costly budgetary intervention to mitigate adverse effects on employment. In turn, high public expenditure perpetuated the heavy tax burden with likely negative implications for potential growth.

\section{The staff pressed for comprehensive} reform of labor market institutions to raise the labor utilization rate. It argued for reshaping the employment protection system to clarify the role of the judiciary and reduce firing $\operatorname{costs}^{15}$ and a reorientation of the entitlement system toward encouraging job search. Indexation of benefits and minimum wages should henceforth be linked to underlying inflation and not to wages and the duration of benefits could be further shortened. Regarding active labor market policies, staff encouraged measures that emphasized training, especially on the job, and facilitated the hiring of low-skilled youth (Box 4). It also underscored that product market deregulation had raised the potential returns from increased labor market flexibility but that, aside from wage moderation, labor market rigidities appeared to have increased in the 1990s (Figure 15).

\section{The authorities responded that} several of the staff's suggested labor market reforms were under way or under consideration, but saw the lowering of benefits and replacement rates as running counter to the government's emphasis on social solidarity. In addition, they stressed that recent increases in benefits and minimum wages had helped sustain confidence and household consumption. They had also extended the possibility for social partners to negotiate derogations from the strictures of the 35-hour workweek - which so far has been used only marginally — and allowed for the establishment of private employment agencies. They agreed that cumbersome labor laws and excessive court involvement in layoffs offered "employment protection" in the short run, but ultimately

\footnotetext{
${ }^{15}$ Well-publicized studies by Blanchard and Tirole suggest replacing all existing forms of employment protection with a simple layoff tax, while greatly simplifying the judicial process. The authorities considered this proposal interesting but at odds with the country's mainstream thinking and, consequently, unlikely to be considered in the near future.
} 


\section{Box 4. Youth Unemployment, Job Mobility, and Wage Growth}

Over the last decade, similar average unemployment rates in France and Germany have masked large differences in youth unemployment. While the latter matched the average in Germany, in France it has been about twice as high (Figure).

Economic theory does not unequivocally predict the role of early labor market experiences for long-term wage and employment prospects. High youth unemployment rates reflecting excessive job mobility may prevent on-the-job training as human capital theory suggests that experience accumulation depends on the amount of time spent working. Conversely, high job mobility of the young may not be a problem if it reflects search for better employment opportunities. However, high unemployment does not necessarily imply high mobility.
Aggregate Unemployment Rate by Age

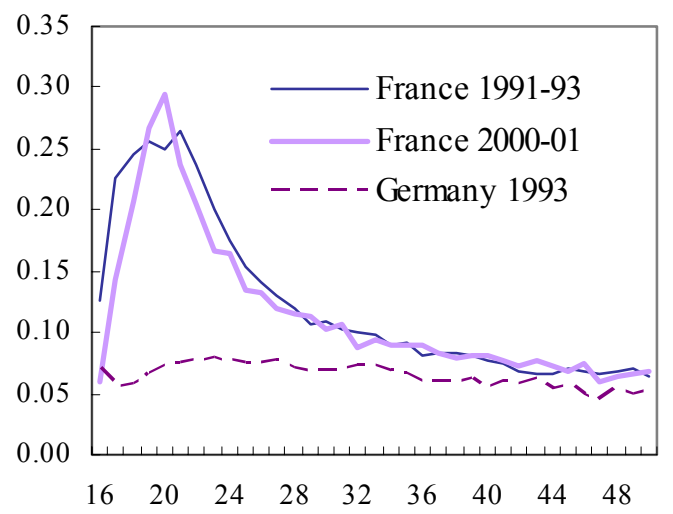

Staff analysis suggests that youth in France are not in a beneficial search-induced highmobility equilibrium and that returns to on-the-job experience are lower in France (see Selected Issues paper). In fact, job mobility and its contribution to wage growth are similar in both Germany and France. From a decomposition of wage growth in "on-the-job" and "between-jobs" wage growth, it appears that "between-jobs" growth contributes similarly to the wage growth of young workers in both countries. Moreover, differences in the amount of time spent working due to different unemployment spells are insufficient to explain lower onthe-job wage growth in France. Consequently, lower returns to experience seem a likely, if partial, culprit. One implication is that on-the-job experience appears to be an imperfect substitute for explicit training. A comparison of hourly wage profiles suggests that workers with vocational and intermediate level of education might be undertrained in France compared to Germany. For these workers, more explicit training arrangements may be beneficial, provided their cost is shared between the worker and the employer. Recent measures to promote training contain elements that move in this direction.

reduced labor demand by making firing decisions costly and uncertain. For the time being, they had deferred the initiative for modifications in this area to social partners, which seemed however reluctant to take up negotiations in earnest. The staff acknowledged that several of these measures were beneficial, while emphasizing that increases in benefits and minimum wages would have adverse long-term effects on labor market performance.

25. The staff was critical of the new "social cohesion" program. While the plan is commendable in its striving for reduced welfare dependency and exclusion, it falls back into 
the trap of using fiscal resources to promote employment, initially outside the private sector. Inter alia, the program aims to move a large number of young unskilled unemployed into jobs combined with training with exoneration from social security contributions. Public sector jobs will be created for 100,000 of them. An individual contract is to be signed with revamped local employment agencies, and close follow-up is envisaged, which will require increased budgetary resources. The staff argued for a better balance between rights and obligations of participants so as to enhance the focus on moving people into market jobs.

26. Progress has been ongoing in product market reform, but a broader approach is needed. The authorities noted that the regulatory burden on existing firms had eased and formalities involved in creating new enterprises been simplified appreciably. Network industries were being opened to cross-border competition, and the statutes of the public electricity and gas companies $(E D F / G D F)$ had been changed - in the face of strong employee opposition - to introduce the possibility of private participation in their capital. The authorities saw this change as significantly outweighing the concessions that had been made (such as the retention of a majority stake). A new government agency (Agence de Participations de l'Etat) had strengthened the governance of state participation in enterprises, and divestiture was being accelerated. The authorities concurred with the staff on the benefits of speeding up the transformation of public enterprises and closing the considerable transposition gap in EU internal market and competition directives. They also intended to modify legislation to strengthen competition in the retail distribution sector.

\section{The staff welcomed the acceleration of divestiture but was critical of the} heightened emphasis on "national champions". This emphasis was most recently manifested in the support for a French partner in a pharmaceutical merger and the rescue of an engineering firm. The staff noted that such an approach reduced competition, created vested interests, deterred private investors, and constituted a form of protectionism. The authorities dismissed these concerns and made clear they were committed to divesting the state from participation in commercial activities, unless a strategic interest was involved. They felt that, in supporting key industries, France was in practice no different from other countries, but was simply more vocal about it, and that, in contrast to the rhetoric, France was in reality very open to foreign participation. In any event, the new bankruptcy law would make involvement of the state in rescue operations increasingly unnecessary as it would allow easier restructuring of enterprises as going concerns.

\section{Financial Sector}

28. The FSAP found that supervision and oversight of the financial sector are of high standard and supervisory staff is highly qualified, and the authorities agreed with most of its recommendations (Box 5). With the economic upturn, corporate deleveraging, and equity markets well above post-bubble lows, banks and insurance companies had seen their profitability and solvency strengthen. The FSAP found no immediate systemic risks on present analysis, but recommended further strengthening of supervision through enhanced coordination between the various supervisory agencies and vigilance on banks' risk 


\title{
Box 5: FSAP Main Policy Recommendations
}

\begin{abstract}
While finding the financial sector resilient and its oversight and supervision of high quality, the FSAP made the following main recommendations:
\end{abstract}

For efficiency reasons, ongoing efforts to diminish state influence over savings allocation through administered savings schemes and fiscal incentives should be accelerated, with a view to eventually establishing a fully market-based system. The key objective should be their orderly phasing out. In the short term, the focus should be on reducing the distortions caused by the schemes.

Given the degree of concentration in the financial system, continued vigilance is needed to preserve strong competition. Ongoing efforts to improve disclosure and pricing transparency for banking services should be continued. The separation of the postal office's banking activities and their subjection to standard prudential requirements is welcome, but the newly created bank should be put as soon as possible on a "level-playing field" with other banks. Competition at the retail level and the availability of financial services could further be enhanced by eliminating the notion of "national champions" and introducing the positive credit registry.

The corporate governance and risk-taking of banks need to be monitored carefully, particularly when they expand into unfamiliar activities. Potential pressure on banks to overexpand could be eased by reducing barriers to the return of profits to owners.

Creditor rights should be improved to facilitate credit provision. The ongoing reform of the corporate bankruptcy legislation will clarify and limit the liability of creditors, while at the same time enhancing the survival chances of troubled companies. In addition, banks should be allowed to write off nonperforming loans without jeopardizing their legal claim on the debtor.

The overall legal and institutional framework for AML/CFT should be further improved in some areas, mainly: the implementation of UN Security Council Special Resolution on terrorism financing; the overall quality of suspicious transactions reporting; AML/CFT regulation, supervision and enforcement for sectors other than credit institutions and certain investment firms; and criteria for when financial institutions should exercise increased diligence.

exposure. The authorities, while acknowledging that mechanisms that encourage strong corporate governance in joint-stock companies were less effective for mutual banks, noted that such banks had developed equivalent internal mechanisms to underpin good governance. Moreover, they felt that risks were minimal as their management had proven to be trustworthy and often on the conservative side. Risks involved in branching out in nontraditional activities — which had increased recently — appeared limited as it typically occurred in the context of acquisitions, which included the required expertise, and without government guarantees. 
29. There was consensus that the financial sector should be made more efficient by reducing state intervention. Staff analysis suggests that administered savings schemes interfere with monetary transmission and efficient resource allocation (see Selected Issues paper). Moreover, in light of population aging, it felt it would be sensible to focus budgetary resources on the newly-created voluntary retirement savings plan (the tax exemptions on administered savings schemes cost the budget about 0.25 percentage point of GDP per year). The staff also noted that usury rates, which are set at four-thirds of actual average interest rates, exclude some segments of the population from access to financial services, especially when interest rates are low. The authorities expressed increased readiness to contemplate changes in administered savings schemes and lift other restrictions (e.g., the interdiction of remuneration of sight deposits and the obligation to provide checks free of charge), but felt that this could not be done as immediately as staff suggested. The authorities acknowledged the need for a full and swift implementation of measures to promote disclosure and transparency of pricing of financial services, while considering the recent increases in bank fees a normalization rather than an indication of lack of competition. They emphasized that the creation of a postal bank would level the playing field in terms of supervision as the financial services hitherto provided by the post office would be subject to regular supervision.

30. The removal of obstacles to financial innovation in the area of mortgage and consumer credits is likely to be welfare improving. The authorities, who considered the French savings ratio as structurally too high, were reviewing options to facilitate household access to asset-backed credits such as mortgages and home equity loans. There were no legal obstacles, but cumbersome and expensive approval procedures as well as problems in seizing collateral were considered significant impediments. The supervisory authorities expressed concerns about the volatility of asset prices and its repercussions on the amplitude of cyclical fluctuations in demand and banks' and households' financial stability. They placed emphasis on safeguards in the use of instruments such as home equity loans.

\section{E. Other Issues}

31. France continues to strengthen its framework to combat money laundering and terrorist financing, remaining proactively involved in these efforts at the European and international levels, but further efforts are needed (Box 5). The OECD has judged France's legal framework as conforming to the anti-bribery convention's requirements, but called for a further strengthening of measures for more effective prevention and sanctioning of bribery of foreign public officials. ${ }^{16}$

32. While supporting the Doha round of multilateral trade talks, the authorities pressed strongly for what they termed a "balanced" result. In their view, the EU initiatives and offers, notably with respect to the abolition of agricultural export subsidies had

\footnotetext{
${ }^{16}$ See OECD website under the focus topic "fighting bribery and corruption": http://www.oecd.org/dataoecd/36/36/26242055.pdf
} 
not drawn an equivalent response from other major trading nations. Singapore issues - in particular trade facilitation and the protection of foreign investment-remained important, although they agreed that successful conclusion of the Round would require flexibility on all issues by all parties. More generally, the authorities expressed concern that unfettered trade liberalization might not benefit developing countries, which often did not have the ability to compete in global markets. France favored the development of local agricultural production in Africa, preferential trade agreements with the ACP countries, insurance mechanisms against volatility in certain agricultural prices such as cotton, and closer regional cooperation, reinforced by regional customs unions. The staff pressed the case for a constructive approach toward the WTO framework agreement then under negotiation, and encouraged early implementation in France of CAP reform (currently set for 2007).

33. The authorities were determined to further increase ODA from the 2003 level of 0.41 percent of GNP to the U.N. target of 0.7 percent of GNP in 2012. They noted that their current level was the highest among G-7 countries and concentrated in Africa.

\section{Staff Appraisal}

34. The economy has staged a strong recovery and key reforms are making headway in tackling the costs of aging, but serious challenges persist to secure higher potential growth and long-term fiscal sustainability. The recovery is being driven by domestic demand thanks in part to skillful implementation of key structural reforms geared to promoting confidence. Following last year's milestone pension reform, health care reformanother key step toward fiscal sustainability - has been adopted. Ongoing and planned reforms in product, labor and financial markets are likely to boost growth. At the same time, however, much-needed fiscal consolidation is thwarted by heavy reliance on budgetary resources to raise employment, while an impending demographic shock casts a shadow over long-term growth prospects. The solution lies in an improvement of labor market institutions to raise labor utilization without adverse consequences on the budget and in steadfast fiscal consolidation.

35. The economic recovery appears to be well-sustained, providing the sought-for opportunity to proceed with sustained fiscal adjustment. Growth is set to average about $2 \frac{1}{2}$ percent per year during 2004-05, with risks broadly balanced and stemming predominantly from the external side. Monetary conditions are likely to remain quite accommodative as domestic demand is running ahead of that of the rest of the euro area. Consequently, the recovery is unlikely to be threatened by a resumption of appreciable underlying fiscal adjustment. Temporary incentives to promote household consumption could be withdrawn, and all revenue windfalls from higher-than-expected growth should be saved.

\section{Securing long-run fiscal sustainability requires growth-enhancing structural} reforms and up-front fiscal consolidation. The authorities' approach needs to be strengthened on both fronts. The emphasis on growth-enhancing structural reforms is welcome, but it needs to be backed up by the specification and implementation of reforms that will effectively raise labor utilization without burdening the budget. In the absence of 
such reforms, up-front consolidation should be pursued at a pace such as to achieve a small structural surplus by the end of the decade when the costs of aging set in. And even with a more decisive reform agenda, consolidation efforts need to be strengthened compared to current plans. Once a reasonable fiscal down payment has been made, and the structural balance is in a durable small surplus, a larger share of spending restraint should be allocated to growth-enhancing tax cuts.

37. A fundamental overhaul of labor market policies will be required to resolve the tension between the policies followed to raise labor utilization and achieving fiscal consolidation. As a priority, the employment protection regime and the role of the judiciary in layoffs should be modified. The focus of the entitlement system needs to shift further from income support to moving people into market jobs. Real increases in minimum wages and benefits should be avoided to prevent exclusion of a rising number of potential workers or welfare recipients from activity. Any new labor market programs should be funded by a redeployment of existing resources; this applies in particular to the new "social cohesion" program, which has a large budgetary cost. Ongoing initiatives to tighten job-search requirements, establish private employment agencies, and reduce the duration of unemployment benefits will improve labor market performance with likely positive effects on the budget.

38. Near-term nominal budget objectives appear within reach, but are unambitious in terms of structural adjustment, especially in light of the stronger-than-envisaged recovery. With higher-than-anticipated growth, and owing to commendable expenditure restraint at the central government level, the targeted reduction of the deficit to just below 3 percent of GDP in 2005 should be feasible, but would represent little structural adjustment. The targets for 2005 and beyond should be made more ambitious. This could inter alia be achieved by advancing and strengthening health care reforms and by reducing the size of the civil service in the context of the ongoing wave of retirements. Well-designed decentralization that leads to efficiency improvements could be a further source of potential savings.

39. The present fiscal framework needs to be strengthened. The ongoing implementation of an output-oriented budget law provides an improved framework to control spending, while stepped-up interministerial coordination is helping to address an ingrained spending culture. Proposals to supplement the framework with multiannual social security budgets and an internal stability pact with local authorities should be implemented. To ensure transparency and the correction of past overruns, multiyear spending ceilings should be set for the general government in terms of the level of spending. To raise the political cost of deviating from commitments, an independent agency could be established to conduct forward-looking budget assessments, and the frequency of publication of general government accounts could be raised. Finally, broadly symmetrical cyclical policy behavior is essential for any rational fiscal policy rule, thus favoring a rule - over the current government proposal - that permits full rather than partial operation of automatic stabilizers. 
40. Reducing the tax burden is desirable while modifications in the tax structure could yield efficiency gains. Ideally, room should be made on the expenditure side to permit the phasing out of the tax on capital (taxe professionnelle), a key source of revenue for local authorities. But the tax raises considerable revenues and other options for local authority financing will need to be explored. Consideration should be given to relying more on user fees, increasing the intake from real estate taxes, phasing out VAT exemptions and reduced rates, or placing a local surcharge on a broad revenue base.

41. In product markets, the ongoing efforts to lighten the regulatory burden, simplify administrative procedures, and promote divestiture are welcome. The reform of the $E D F / G D F$ statute marks a major step forward in this area. More broadly, the government should follow through resolutely on its intention to withdraw from commercial activities, as market conditions permit. The reform of the corporate bankruptcy legislation will help clarify and limit the liability of creditors, while enhancing the survival chances of troubled companies. However, more needs to be done to strengthen competition, in particular by improving price transparency in financial services, and closing the significant transposition gap of EU directives. The attractiveness of France as a place to produce and invest is best defended by structural reforms in goods and labor markets. Emphasis on "national champions" goes against the grain of such reforms and risks manipulation by vested interests.

42. This year's FSAP confirmed the resilience of France's financial system and the high quality of oversight and prudential supervision. The stress tests point to a resilient system, and no systemic weaknesses were identified. Nonetheless, continuing vigilance is needed, especially with respect to banks' potentially risky expansions, and cooperation among supervisory agencies could usefully be further strengthened. Some weaknesses in the system for countering money laundering and the financing of terrorism and in the payment systems area need to be addressed.

43. Remaining administrative interventions in the financial system should be phased out to improve resource allocation and the economy's dynamism. The social goals pursued through administered savings schemes could be achieved more efficiently - at a lower cost to the budget and with less drag on monetary policy transmission-by more direct means. Limits on lending interest rates should be lifted, and the restrictions on remunerating sight deposits and charging for the use of checks should be lifted. Mortgage-based lending should be further developed by lowering refinancing costs and removing cumbersome regulations.

44. In the trade area, France should associate itself fully with efforts to bring the Doha round to a successful conclusion, in particular by supporting comprehensive liberalization of agricultural markets. National implementation of the June 2003 reform of the CAP could also usefully be moved forward. France's contribution to development through its relatively high level of ODA and its intention to reach the UN target by 2012 is commendable.

45. It is proposed that the next Article IV consultation take place on the standard 12-month cycle. 
Table 1. France: Main Economic Indicators, 2000-09

(Annual percentage change; unless otherwise indicated)

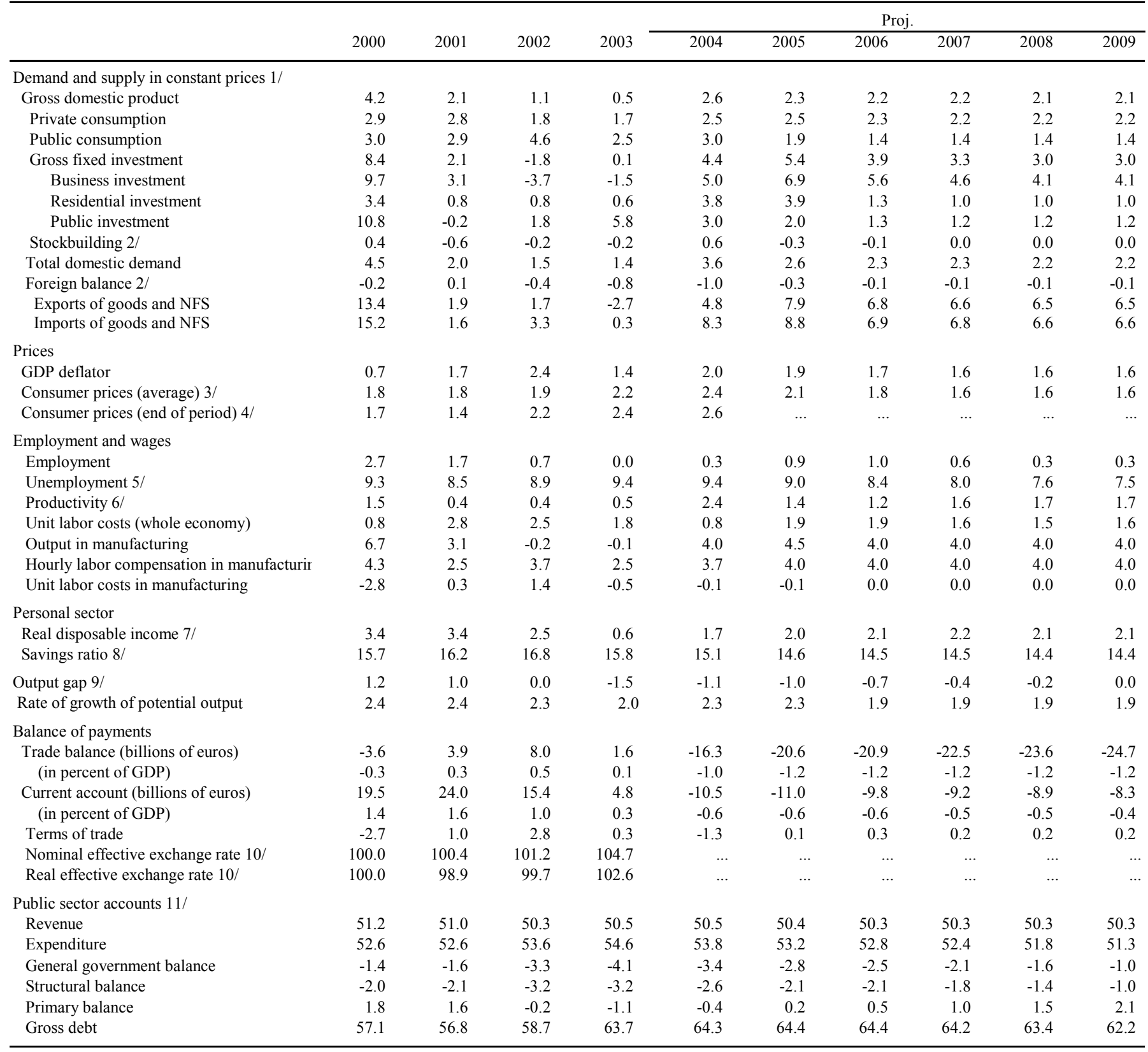

Sources: Bank of France; data provided by the authorities; and IMF staff estimates.

1/ Data from the INSEE quarterly national accounts system.

2/ Change as percentage of previous year's GDP.

3/ Harmonized CPI.

4/ For 2004, year on year, July.

5 / In percent of labor force; harmonized index.

6/ GDP over total employment.

7/ Personal disposable income deflated by the implicit deflator for private consumption.

8/ In percent of household disposable income.

9/ In percent of potential GDP.

10/ Index; Base 2000=100.

11/ In percent of GDP; data for 2001-02 excludes the proceeds from the sale of UMTS licenses, which amount to about 0.1 percent of GDP. 
Table 2. France: Vulnerability Indicators, 1999-2004

(In percent of GDP)

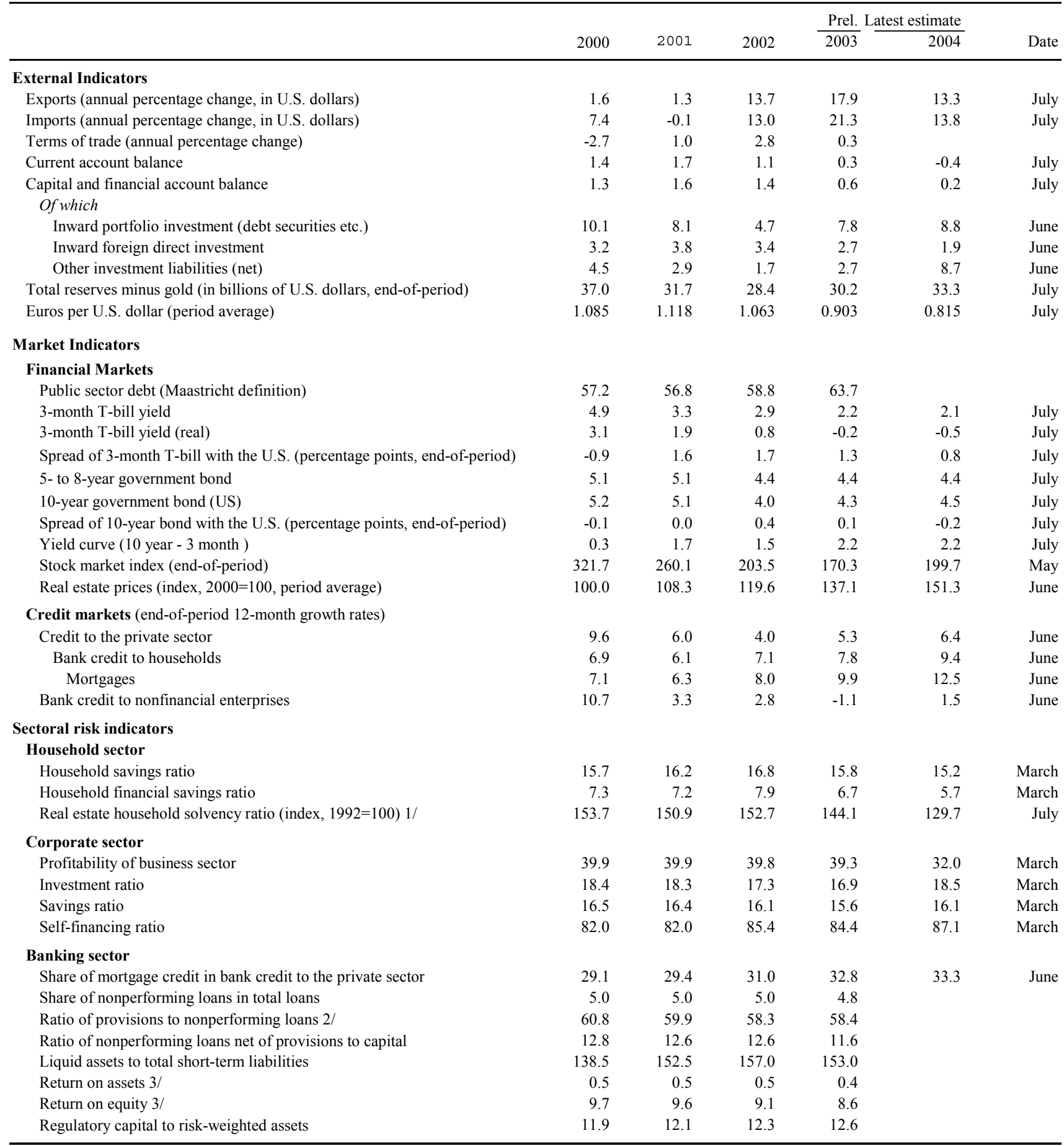

Sources: Banque de France; IMF, International Financial Statistics; Bloomberg; FNAIM; and Commission Bancaire .

1/ This index combines the effect of real disposable income, repayment conditions for loans, real estate prices, and public incentives for the purchase of houses.

2/ Refers to metropolitan France.

3/ All credit insitutions aggregated data on a parent-company basis. 


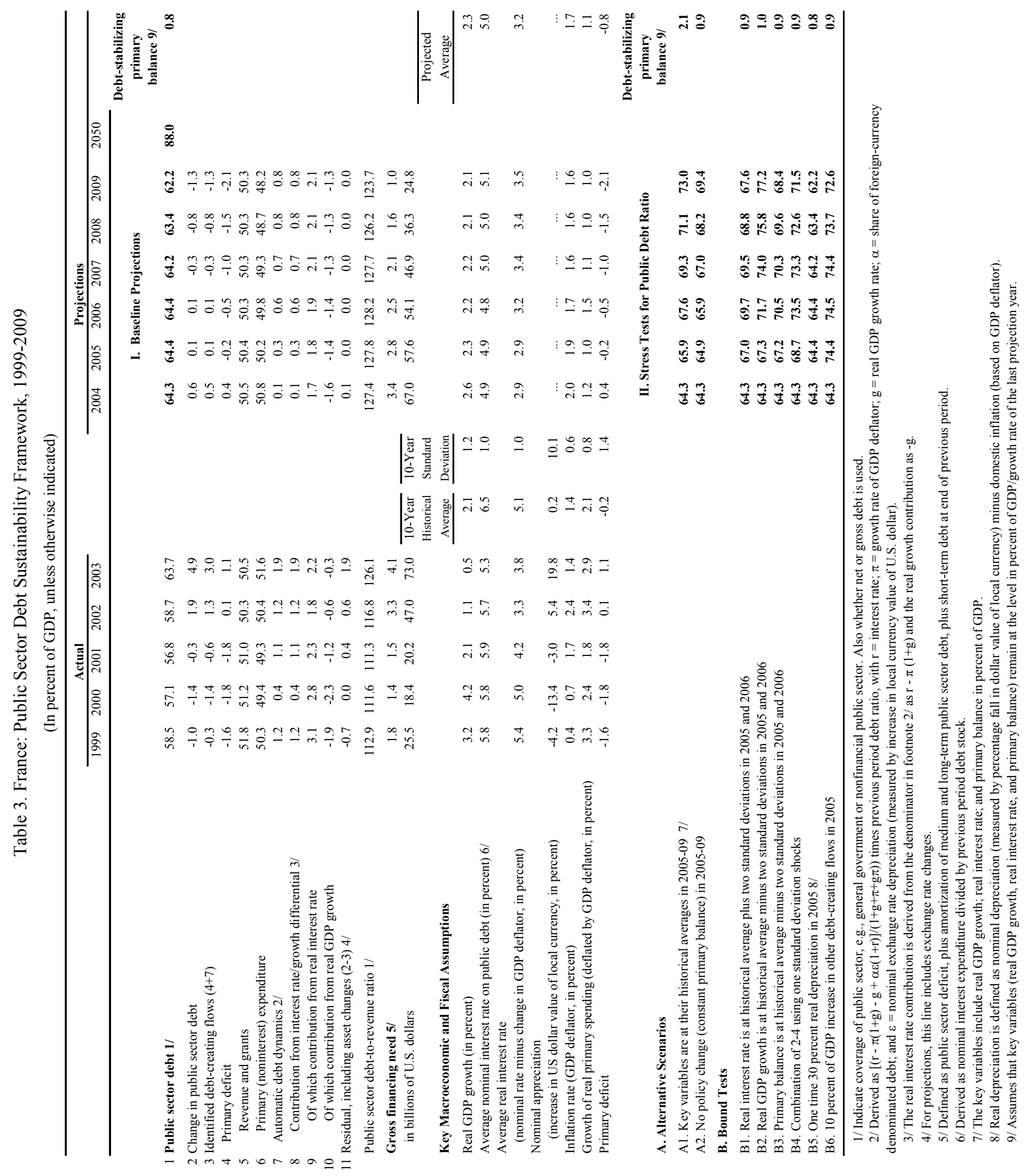


Table 4. France: General Government Accounts, 1996-2003 1/

(In billions of euros)

\begin{tabular}{|c|c|c|c|c|c|c|c|c|}
\hline & 1996 & 1997 & 1998 & 1999 & 2000 & 2001 & 2002 & 2003 \\
\hline \multicolumn{9}{|l|}{ General government } \\
\hline Revenue & 623.1 & 649.7 & 668.4 & 701.9 & 728.0 & 753.3 & 768.6 & 786.6 \\
\hline Tax revenue & 542.5 & 562.8 & 584.9 & 616.1 & 638.4 & 658.9 & 668.2 & 682.6 \\
\hline \multicolumn{9}{|l|}{ Of which } \\
\hline VAT & 92.4 & 96.3 & 99.2 & 102.6 & 104.5 & 106.2 & 108.4 & 109.0 \\
\hline Income tax & 43.3 & 40.2 & 41.8 & 46.3 & 49.8 & 48.7 & 45.8 & 46.7 \\
\hline Corporate tax & 21.8 & 26.3 & 28.7 & 34.4 & 37.7 & 44.3 & 39.7 & 37.4 \\
\hline TIPP & 22.6 & 22.8 & 23.5 & 24.7 & 24.3 & 23.6 & 24.4 & 23.4 \\
\hline Nontax revenue & 80.6 & 86.9 & 83.5 & 85.8 & 89.6 & 94.4 & 100.4 & 104.0 \\
\hline $\begin{array}{c}\text { Expenditures } \\
\text { Of which }\end{array}$ & 672.5 & 687.7 & 703.2 & 725.8 & 748.0 & 775.8 & 818.4 & 851.1 \\
\hline Salaries & 168.5 & 172.7 & 178.9 & 185.6 & 191.7 & 199.2 & 209.2 & $\ldots$ \\
\hline Pensions & 121.2 & 125.1 & 129.3 & 134.2 & 137.8 & 144.6 & 149.6 & $\ldots$ \\
\hline Health expenditure & 65.5 & 66.3 & 69.2 & 70.5 & 76.7 & 81.2 & 87.0 & $\ldots$ \\
\hline Other social transfers & 104.2 & 110.1 & 111.0 & 113.8 & 115.0 & 116.6 & 128.3 & ... \\
\hline Balance & -49.4 & -38.0 & -34.9 & -23.9 & -20.0 & -23.8 & -50.4 & -64.6 \\
\hline Primary balance & -1.7 & 8.3 & 11.9 & 21.1 & 25.7 & 23.7 & -2.3 & -17.3 \\
\hline Structural balance & -26.7 & -13.8 & -23.4 & -18.4 & -28.4 & -30.4 & -48.7 & -50.3 \\
\hline Central government balance & -45.1 & -44.7 & -39.0 & -35.3 & -34.8 & -34.4 & -59.6 & -61.6 \\
\hline Social security balance & -5.3 & -5.4 & -1.4 & 3.7 & 7.2 & 4.0 & -4.1 & -11.1 \\
\hline Local government balance & 0.7 & 2.9 & 4.0 & 4.3 & 2.8 & 2.1 & 2.7 & 1.7 \\
\hline ODAC balance & 0.3 & 9.2 & 1.5 & 3.4 & 4.8 & 5.7 & 9.8 & 6.5 \\
\hline Gross debt & 691.8 & 741.6 & 777.3 & 792.1 & 812.1 & 838.7 & 897.5 & 992.1 \\
\hline Interest payments & 47.7 & 46.3 & 46.8 & 45.0 & 45.7 & 47.5 & 48.1 & 47.3 \\
\hline \multicolumn{9}{|l|}{ Memorandum items } \\
\hline Nominal GDP 2/ & $1,212.2$ & $1,251.2$ & $1,305.9$ & $1,355.1$ & $1,420.1$ & $1,475.6$ & $1,526.8$ & $1,557.2$ \\
\hline Structural nominal GDP & $1,248.1$ & $1,289.4$ & $1,326.2$ & $1,362.3$ & $1,404.6$ & $1,461.0$ & $1,528.2$ & $1,581.3$ \\
\hline
\end{tabular}

Sources: INSEE; and IMF staff calculations.

1/ Excludes UMTS receipts.

2/ Annual national accounts; Maastricht definition. 


\section{FRANCE: Fund RELATIONS}

As of June 30, 2004

I. Membership Status: Joined December 27, 1945; Article VIII.

II. General Resources Account:

Quota

Fund holdings of currency

Reserve position in Fund

III. SDR Department

Net cumulative allocation

Holdings
SDR Million

$10,738.50$

$6,709.06$

$4,029.39$

SDR Million

$1,079.87$

536.97
Percent of Quota

100.00

62.48

37.52

Percent of Allocation

100.00

49.73

IV. Outstanding Purchases and Loans: None

V. Latest Financial Arrangements: None

VI. Projected Payments to Fund (SDR million; based on existing use of resources and present holdings of SDRs):

Forthcoming

$\underline{2004} \quad \underline{2005} \quad \underline{2006} \quad \underline{2007} \quad \underline{2008}$

Principal

Charges/interest

$\underline{4.92} \quad \underline{9.96}$

$\underline{9.96}$

$\underline{9.96}$

$\underline{9.99}$

Total 4.92

9.96

9.96

$9.96 \quad 9.99$

VII. Implementation of HIPC Initiative: Not applicable

VIII. Safeguards Assessments: Not applicable

IX. Exchange Rate Arrangements:

- Since January 1, 1999, France has participated in Stage III of the European Economic and Monetary Union (EMU).

- In accordance with EU regulations and the relevant UN Security Council resolutions, certain restrictions are maintained on the making of payments and transfers for current international transactions with respect to the former government of Iraq, the former government of Liberia, Myanmar, certain individuals associated with the previous government of the former Republic of 
Yugoslavia, and Zimbabwe. Financing of, and financial assistance related to, military activities in the Democratic Republic of the Congo (from October 1, 2003), Somalia (effective January 27, 2003), and Sudan (from January 26, 2004) are prohibited. Restrictions also apply on transfers with respect to the Taliban and individuals and organizations associated with terrorism. The restriction with respect to the Socialist People's Libyan Arab Jamahiriya has been notified to the Fund under Decision No. 144-(52/51); EBD/93/92 (12/27/93) and Supplement 1 (1/6/94).

Measures have been taken to freeze accounts of listed persons and entities linked to terrorists pursuant to the relevant EU regulations and UN Security Council resolutions.

\section{Article IV Consultation:}

The last Article IV consultation was concluded on October 8, 2003. France is on the standard 12-month consultation cycle.

\section{FSAP Participation and ROSC:}

\section{Date Issued Country Report} No.

Transparency in Monetary and Financial Policies Fiscal Transparency Module

Fiscal Transparency, Transparency in Monetary and Financial Policies-Update

$10 / 17 / 00$

$10 / 17 / 00$

$11 / 05 / 01$

$01 / 197$

Fiscal Transparency Module_-Update

$11 / 13 / 02$

$02 / 248$

Transparency in Monetary and Financial Policies - Update

$11 / 13 / 02$

$02 / 248$

Data Module
$10 / 29 / 03$

$03 / 339$ 


\section{FRANCE: STATISTICAL INFORMATION}

France's economic database is comprehensive and of high quality. The authorities regularly publish a full range of economic and financial data and calendar dates of main statistical releases are also provided. The transmission of data in electronic form from INSEE and the profusion of data from various institutions (Banque de France, INSEE, ministry of finance, ministry of labor and solidarity) have helped to build an infrastructure in which all data can be easily accessed through the Economic Data Sharing System. As a subscriber to the Special Data Dissemination Standard (SDDS), France posts its metadata on the Fund's Dissemination Standards Bulletin Board (DSBB) on the Internet.

Since the beginning of 1999, France's monetary and banking statistics methodology has changed to reflect the standards of the European Monetary Union. Statistics for International Financial Statistics on banking institutions and monetary aggregates are prepared on a monthly basis and are timely.

France adopted the European System of Integrated Economic Accounts 1995 (ESA95) in 1999. Although data for GDP and its components are available since 1978, data for the household, corporate, and public administration accounts are only available since 1992. France produces annual national accounts aggregates on a quarterly and annual basis, but the two estimates differ slightly due to revision practices.

Recent data issues include the need to provide monthly or quarterly developments not only in the finances of the central government, but also in those of the social security and local governments. These data should be presented in a comprehensive fashion and on a national accounts basis, to facilitate monitoring of public finances. 


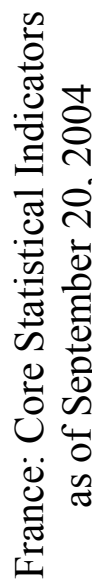

\begin{tabular}{|c|c|c|c|c|c|c|c|c|}
\hline 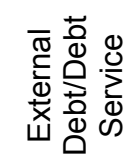 & $\frac{8}{3}$ & $\begin{array}{l}\text { O } \\
\text { Oे } \\
\frac{8}{<}\end{array}$ & 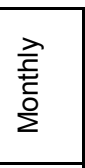 & 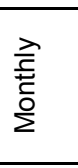 & 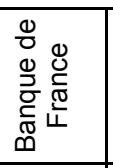 & 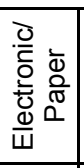 & $\begin{array}{l}\overline{0} \\
\frac{0}{0} \\
\frac{0}{0} \\
\frac{0}{2} \\
0 \\
\end{array}$ & $\begin{array}{l}\text { ते } \\
\text { 晜 } \\
\text { ¿ }\end{array}$ \\
\hline $\begin{array}{l}\text { n } \\
\text { 仓 } \\
\text { 员 } \\
\text { 0 }\end{array}$ & $\begin{array}{l}\text { ช̃ } \\
\text { ठิ }\end{array}$ & $\begin{array}{l}\text { O } \\
\text { O } \\
\frac{3}{<}\end{array}$ & $\begin{array}{l}\text { 츨 } \\
\text { 产 } \\
\frac{0}{0} \\
0\end{array}$ & 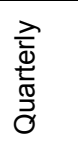 & $\begin{array}{l}\text { 岀 } \\
\underline{\cong}\end{array}$ & 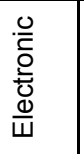 & $\begin{array}{l}\overline{0} \\
\frac{0}{\frac{1}{0}} \\
\frac{0}{0} \\
\frac{0}{2}\end{array}$ & 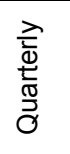 \\
\hline 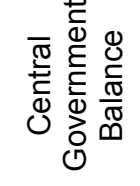 & $\frac{8}{3}$ & $\begin{array}{l}\dot{0} \\
\stackrel{0}{0} \\
\dot{0}\end{array}$ & 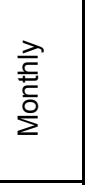 & 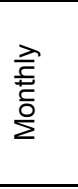 & 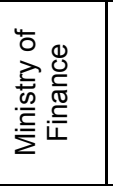 & $\begin{array}{l}\frac{0}{\bar{\sigma}} \\
\frac{0}{0} \\
\frac{\mathbb{d}}{W}\end{array}$ & 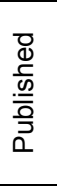 & 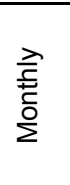 \\
\hline 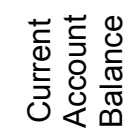 & $\frac{8}{3}$ & 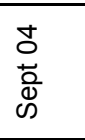 & $\begin{array}{l}\text { 촐 } \\
\text { 竞 } \\
\sum\end{array}$ & 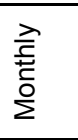 & 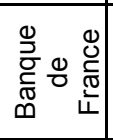 & 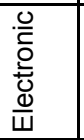 & $\begin{array}{l}\overline{0} \\
\frac{0}{0} \\
\frac{0}{0} \\
\frac{0}{3} \\
0\end{array}$ & $\begin{array}{l}\text { ㄱ. } \\
\text { 壳 } \\
\sum\end{array}$ \\
\hline 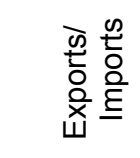 & $\frac{8}{3}$ & 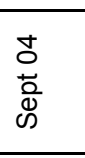 & 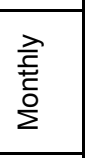 & 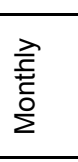 & 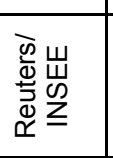 & 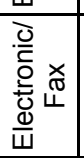 & 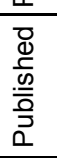 & 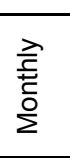 \\
\hline 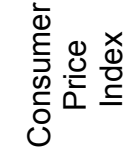 & $\begin{array}{l}\text { J } \\
\text { Oे } \\
\dot{\&}\end{array}$ & 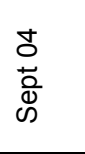 & 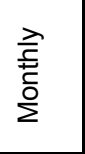 & 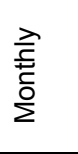 & $\begin{array}{l}\text { 岀 } \\
\underline{\cong}\end{array}$ & 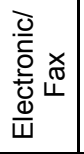 & 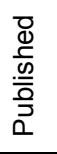 & $\begin{array}{l}\text { ते } \\
\text { 莣 } \\
\dot{\Sigma}\end{array}$ \\
\hline 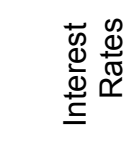 & $\begin{array}{l}\text { N } \\
\stackrel{0}{0} \\
\infty\end{array}$ & $\begin{array}{l}\text { N } \\
\stackrel{0}{0} \\
\infty\end{array}$ & $\stackrel{\grave{\bar{\varpi}}}{\stackrel{\grave{\Phi}}{0}}$ & 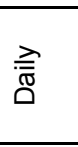 & 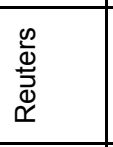 & 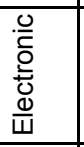 & 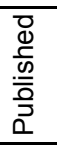 & 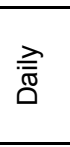 \\
\hline 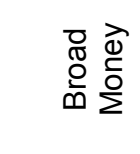 & $\frac{\Xi}{5}$ & $\begin{array}{l}\text { J } \\
\text { Oे } \\
⿱ 亠 䒑\end{array}$ & 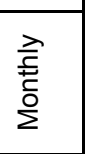 & 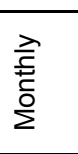 & 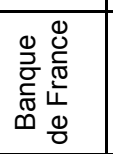 & 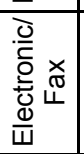 & 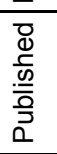 & 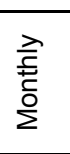 \\
\hline 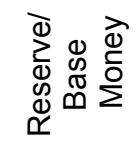 & $\begin{array}{l}\frac{0}{} \\
\stackrel{0}{0} \\
\stackrel{\infty}{\infty}\end{array}$ & 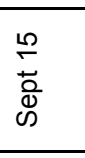 & $\begin{array}{l}\vec{\lambda} \\
\frac{\vec{d}}{\Phi} \\
3\end{array}$ & $\begin{array}{l}\overrightarrow{\bar{v}} \\
\stackrel{\Xi}{J}\end{array}$ & 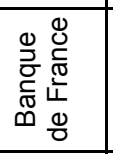 & 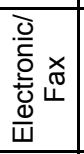 & $\begin{array}{l}\overline{0} \\
\frac{0}{0} \\
\frac{0}{0} \\
\frac{0}{3} \\
0\end{array}$ & $\begin{array}{l}\frac{\vec{x}}{0} \\
\frac{\mathbb{d}}{3}\end{array}$ \\
\hline 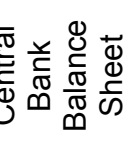 & 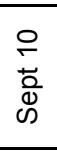 & $\begin{array}{l}\frac{n}{2} \\
\stackrel{0}{0} \\
\infty\end{array}$ & $\begin{array}{l}\text { ते } \\
\stackrel{ \pm}{\Phi} \\
3\end{array}$ & $\begin{array}{l}\frac{\lambda}{\vec{d}} \\
\stackrel{\infty}{3}\end{array}$ & 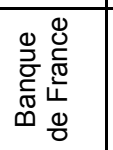 & 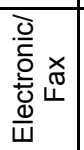 & 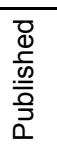 & $\begin{array}{l}\frac{\vec{x}}{ \pm} \\
\stackrel{ \pm}{3}\end{array}$ \\
\hline 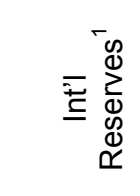 & $\begin{array}{l} \pm \\
\\
5\end{array}$ & 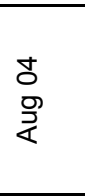 & 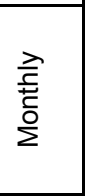 & 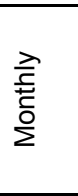 & 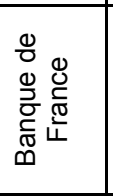 & 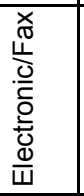 & $\begin{array}{l}\frac{0}{d} \\
\frac{0}{\frac{0}{0}} \\
\frac{\overline{0}}{3} \\
0 \\
0\end{array}$ & 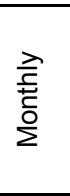 \\
\hline 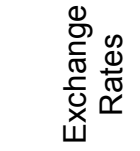 & 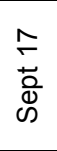 & 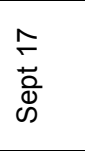 & $\frac{\overrightarrow{\overline{\bar{T}}}}{\Delta}$ & 츰 & 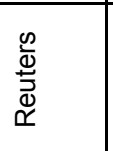 & $\begin{array}{l}\frac{0}{\bar{D}} \\
\frac{0}{0} \\
\frac{\mathbb{d}}{W}\end{array}$ & 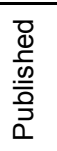 & 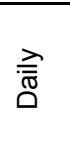 \\
\hline & 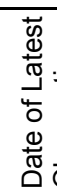 & 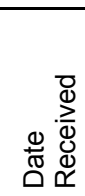 & 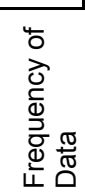 & 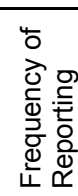 & 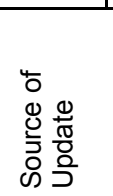 & 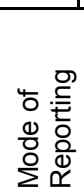 & 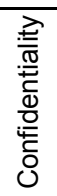 & 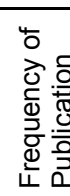 \\
\hline
\end{tabular}




\title{
INTERNATIONAL MONETARY FUND
}

\author{
FRANCE \\ Staff Report for the 2004 Article IV Consultation \\ Supplementary Information \\ Prepared by the European Department \\ (In consultation with the Policy Development and Review Department) \\ Approved by Michael Deppler and G. Russell Kincaid
}

October 15, 2004

\section{This supplement to the staff report for the 2004 Article IV consultation with} France provides an update on recent developments, in particular the authorities' 2005 budget proposal and medium-term fiscal plans. The new information does not alter the thrust of the staff appraisal, but the structural adjustment underlying the draft 2005 budget falls well short of the amount envisaged in the Staff Report. Confidence surveys confirm the strength of domestic demand, but recent indicators are somewhat mixed, and the surge in oil prices has lowered the growth outlook. Despite the hike in oil prices, headline and underlying inflation (12-month rates) both eased in September to 2.2 percent and 1.6 percent, respectively. The draft 2005 budget aims to reduce the general government deficit to 2.9 percent of GDP, relying on higher growth and a substantial one-off measure (the move of the electricity utility's pension fund assets and accompanying future liabilities to the central government). In other developments, in early October, the EU Court of Justice ruled that the French prohibition of paying interest on sight deposits represents a restriction to the freedom of establishment guaranteed by the EC Treaty. Finally, the Camdessus report - to be issued on October 15-is expected to contain comprehensive recommendations on how to lift obstacles to growth, and the authorities have indicated their intention to draw on it for action.

2. The budget foresees steady growth of 2.5 percent in both 2004 and 2005, with domestic demand sustaining the recovery. ${ }^{1}$ The staff now expects a deceleration in 2005 to 2.2 percent, reflecting a new, higher oil price baseline (Table 1$).{ }^{2}$ Recent data releases are somewhat mixed. Overall consumer and business confidence improved, stocks are below their average levels, and perceived inflation has been falling towards the actual rate, lately possibly influenced by the announcement of price cuts by large retailers. However,

\footnotetext{
${ }^{1}$ The authorities' estimate is calendar-day adjusted; with 2004 having 255 working days compared to 252 in 2003 , actual nonadjusted growth could be $0.2-0.3$ percentage points higher. The staff's 2004 projection includes a 0.2 percentage point calendar effect.

${ }^{2}$ The WEO convention is to revise the oil price baseline once future prices on a weighted index of different types of oil deviate by 10 percent from the previous assumption for more than ten days.
} 
employment has so far failed to pick up, nonenergy industrial production growth slowed significantly in August, and the trade balance posted a large deficit.

3. The budget proposal aims to reduce the deficit from 3.6 percent of GDP in 2004 to 2.9 percent of GDP in 2005, through expenditure restraint at the central government level, savings from the health care reform, and the transfer of the electricity company (EDF) pension fund. The 2005 objective remains, as previously announced, that of reducing the general government deficit to below 3 percent of GDP_-specifically to 2.9 percent of GDP. Achievement of this target is facilitated by a 0.4 percentage point of GDP transfer of the $E D F$ pension fund ("soulte") to the central government, as part of the reform of the company's statute ( $\mid 26$ of the Staff Report). Real expenditure growth is planned to be held at 1.6 percent in 2005, the same rate as estimated for 2004, based on a projected deceleration of nominal growth in health care spending from 5.2 percent to 3.2 percent and constant real spending at the central government level. The number of civil servants is to be reduced by 7,200 , corresponding to a replacement of about 7 out of 8 retirees (some 60,000 civil servants are due to retire in 2005, as the wave of retirements begins in earnest). On the revenue side, the exemption of new investments from the taxe professionnelle has been extended until end-2005, the corporate income tax rate will decrease marginally, and the earned income tax credit (PPE) will rise by 4 percent. The budget also includes a number of small tax cuts and various new tax exemptions. Notwithstanding these revenue cuts, the tax burden rises marginally due to the increases in social security contributions introduced by the health care reform. The 2005 budget also takes further steps in the progressive implementation of the 2001 organic budget law, with an emphasis on objectives, outputs, and quantitative performance indicators, which should increase transparency and accountability. ${ }^{3}$ Finally, a modification to the organic law has been proposed requiring that each budget law contain an ex ante specification of the use of any revenue windfalls. The initial proposal - that the majority be devoted to debt reduction and the remainder to temporary tax cuts or investment spending ( $\Phi 20$ of the Staff Report) — was considered by the relevant legal authority (Conseil d'État) as too specific for an organic law. How any windfalls would be allocated in 2005 is currently under discussion.

\section{Over the medium term (2006-08), the authorities reaffirm the intention to} improve the structural balance by about 0.5 percentage point of GDP per year. GDP is assumed to grow by 2.5 percent per year $(0.25$ percentage point above the authorities' estimate of potential growth), and overall real expenditure is targeted to grow by 1.2 percent per year on average. The recent health care reform is expected to limit nominal growth of health spending to 3.6 percent per year during 2006-08. With unemployment assumed to decline gradually, the budget reaffirms the target of balancing the social security accounts by 2007 . The authorities estimate the total underlying adjustment at about 2 percentage points of GDP over the four years 2005-08, bringing the general government structural deficit to just below 1 percent of GDP by the end of the period; staff estimates differ as per the text table below.

\footnotetext{
${ }^{3}$ The update of the fiscal transparency ROSC (SM/04/344 of September 30, 2004) provides further details.
} 
France: 2005 Budget and Medium-Term Fiscal Plans

\begin{tabular}{|c|c|c|c|c|c|c|}
\hline & 2003 & 2004 & 2005 & 2006 & 2007 & 2008 \\
\hline \multicolumn{7}{|l|}{ Budget 2005} \\
\hline Overall balance & -4.1 & -3.6 & -2.9 & -2.2 & -1.6 & -0.9 \\
\hline Tax revenues & 43.8 & 43.6 & 43.7 & 43.7 & 43.7 & 43.7 \\
\hline Expenditures & 54.7 & 54.0 & 53.6 & 53.0 & 52.4 & 51.7 \\
\hline Growth rate of real expenditure (in percent) & 2.0 & 1.6 & 1.6 & 1.3 & 1.3 & 1.1 \\
\hline Real GDP growth (in percent) & 0.5 & 2.5 & 2.5 & 2.5 & 2.5 & 2.5 \\
\hline GDP inflation (in percent) & 1.5 & 2.0 & 1.7 & 1.5 & 1.5 & 1.5 \\
\hline \multicolumn{7}{|l|}{ Staff projections } \\
\hline Overall balance & -4.1 & -3.6 & -3.0 & -3.0 & -2.6 & -2.0 \\
\hline Tax revenues & 43.8 & 43.6 & 43.7 & 43.7 & 43.7 & 43.7 \\
\hline Expenditures & 54.7 & 54.0 & 53.7 & 53.4 & 52.9 & 52.4 \\
\hline Real GDP growth (in percent) & 0.5 & 2.5 & 2.2 & 2.1 & 2.1 & 2.1 \\
\hline GDP inflation (in percent) & 1.4 & 2.0 & 1.9 & 1.7 & 1.6 & 1.6 \\
\hline Structural balance & -3.2 & -2.8 & -2.3 & -2.4 & -2.1 & -1.7 \\
\hline Structural balance excluding $E D F$ transfer & -3.2 & -2.8 & -2.7 & -2.4 & -2.1 & -1.7 \\
\hline \multicolumn{7}{|l|}{ Structural improvement } \\
\hline Authorities' estimate/plans $1 /$ & 0.0 & 0.5 & 0.6 & 0.5 & 0.5 & 0.5 \\
\hline Transfer of $E D F$ pension fund & $\ldots$ & $\ldots$ & -0.4 & 0.0 & 0.0 & 0.0 \\
\hline Nominal potential growth difference & -0.1 & 0.0 & 0.0 & -0.1 & -0.1 & -0.1 \\
\hline Lower nontax revenue $1 /$ & 0.0 & 0.0 & 0.0 & -0.2 & -0.1 & 0.0 \\
\hline Staff estimate/projections & -0.1 & 0.5 & 0.2 & 0.2 & 0.3 & 0.4 \\
\hline
\end{tabular}

$1 /$ The authorities count on an increase in nontax revenue over 2006-08, which the staff did not incorporate.

Sources: Projet de loi de finances 2005; Perspectives Economiques 2004-05; and IMF staff calculations.

\section{The draft $\mathbf{2 0 0 5}$ budget falls short of the staff's recommended substantial} structural adjustment, especially since it is not accompanied by further significant growth-enhancing reforms or durable spending restraint. As regards the nominal deficit, there is sufficient room to achieve the authorities' target of 2.9 percent of GDP with only marginal additional measures, even under the staff's lower growth projections which yield a revised deficit estimate of 3.0 percent of GDP. ${ }^{4}$ More importantly, though, the structural effort (excluding the EDF soulte) amounts to less than $1 / 4$ percent of GDP, about $1 / 2$ percent of GDP less than staff advice. ${ }^{5}$ The reduction in the number of civil servants is welcome in a historical perspective, as it confirms a turnaround in a long-standing trend of expanding

\footnotetext{
${ }^{4}$ Compared to the authorities, the staff deficit projection of 3.0 percent of GDP in 2005 reflects lower real GDP growth and higher health spending growth which raise the deficit, but also a higher GDP deflator, which lowers it.

${ }^{5}$ In November 2003, the Ecofin Council recommended under the SGP's excessive deficit procedure that France reduce its cyclically-adjusted deficit by 0.8 percentage point of GDP in 2004 and at least 0.6 percentage point of GDP in 2005 for a cumulative 1.4 percentage point of GDP.
} 
public sector employment, but it remains limited against the background of the large size and cost of public employment in France (Figure 1). The health care reform is an important step toward longer-term fiscal sustainability. Ensuring early savings would, however, have required advancing or strengthening some of its measures - without which staff remains skeptical about the viability of reducing nominal health care spending growth to 3.2 percent in 2005. On the revenue side, the suspension of earlier plans for further income tax cuts is well-placed and in line with staff advice; at the same time, the budget contains a number of small tax cuts and exemptions that are likely to have little sustained effects on growth and employment and, contrary to announced intentions, increase tax niches.

\section{Insufficient up-front adjustment increases the need to put in place concrete and strengthened measures to achieve the underlying fiscal adjustment planned by 2008 .} Under the staff's projections, an additional 1 percentage point of GDP of structural effort (excluding one-offs) will be necessary compared to the authorities' intentions, even in a strong reform scenario. ${ }^{6}$ Given a record of spending overruns in social security and without more comprehensive spending reforms, there remain doubts about the feasibility of achieving the targeted slowdown in expenditure growth. In addition, because of reliance on a large oneoff measure in 2005, the underlying structural adjustment implied by the authorities' medium-term path is more challenging than it appears, particularly in 2006.

\footnotetext{
${ }^{6}$ The reform scenario is described in the Staff Report's Text Table 1, "B. Fiscal sustainability: reform and consolidation," page 16.
} 
Table 1. France: Main Economic Indicators, 2000-09

(Annual percentage change, unless otherwise indicated)

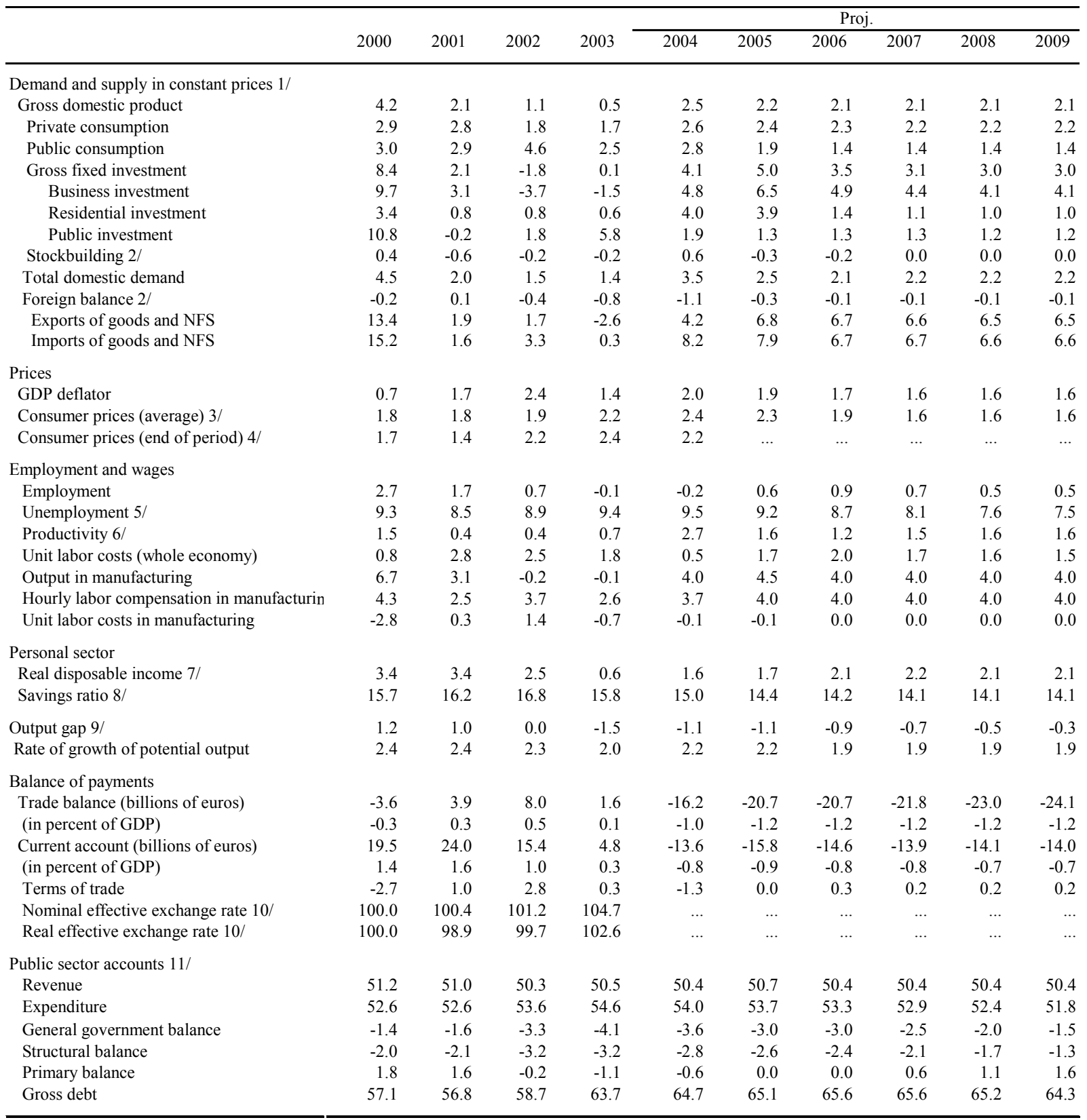

Sources: Bank of France; data provided by the authorities; and Fund staff estimates.

1/ Data from the INSEE quarterly national accounts system.

2/ Change as percentage of previous year's GDP.

3/ Harmonized CPI.

4/ For 2004, year on year, September.

5 / In percent of labor force; harmonized index.

6/ GDP over total employment.

7/ Personal disposable income deflated by the implicit deflator for private consumption.

8/ In percent of household disposable income.

9/ In percent of potential GDP.

10/ Index; Base 2000=100.

11/ In percent of GDP; data for 2001-02 exclude the proceeds from the sale of UMTS licenses, which amount to about 0.1 percent of GDP; data for 2005 exclude the $E D F$ pension fund transfer ( 0.4 percent of GDP). 
Figure 1. France: Public Employment Indicators

(In percent)
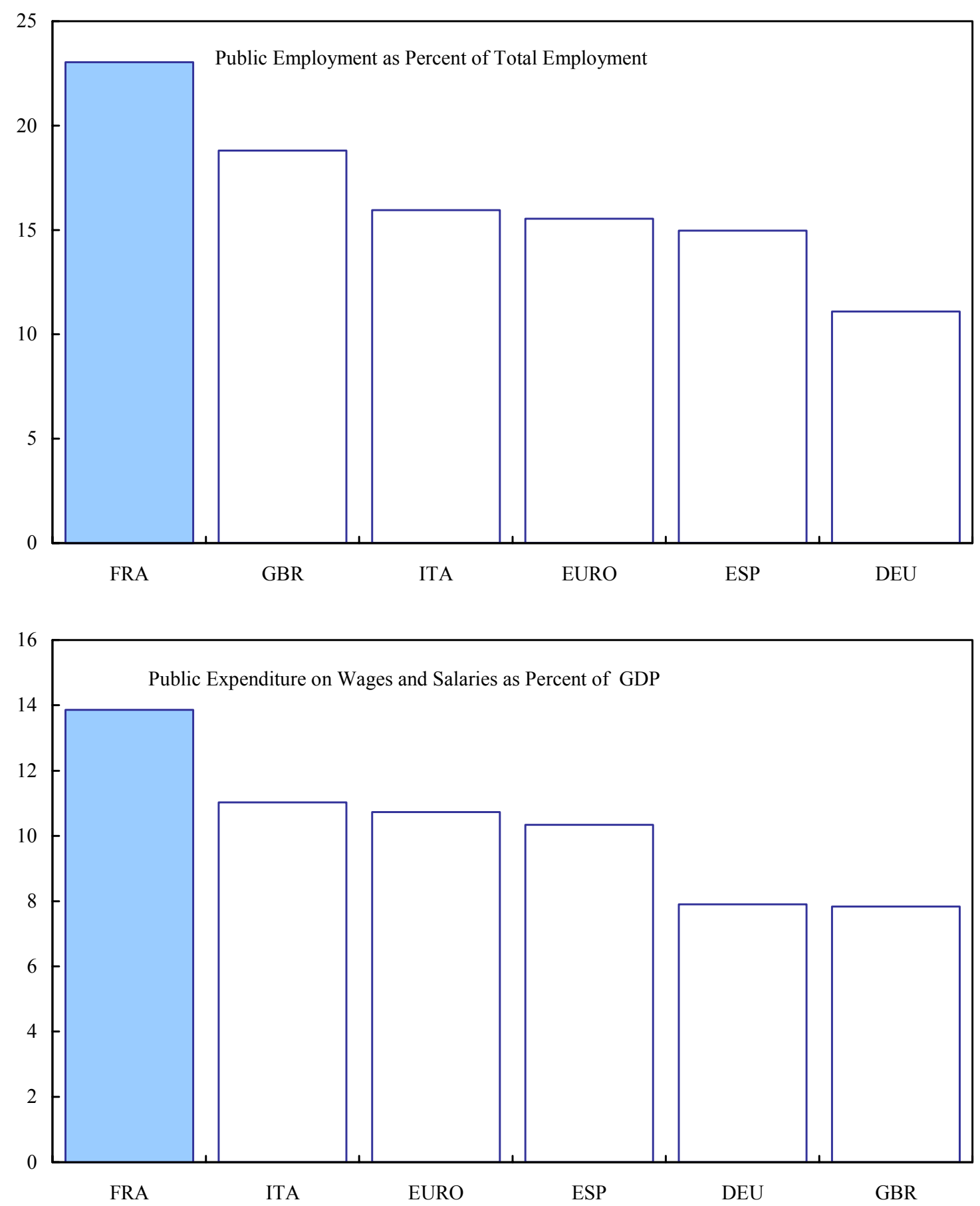

Source: OECD, Analytical Database. 


\section{INTERNATIONAL MONETARY FUND}

EXTERNAL

Public Information Notice

RELATIONS

DEPARTMENT

Public Information Notice (PIN) No. 04/121

International Monetary Fund

FOR IMMEDIATE RELEASE

$70019^{\text {th }}$ Street, NW

November 3, 2004

Washington, D. C. 20431 USA

\section{IMF Concludes 2004 Article IV Consultation with France}

On October 20, 2004, the Executive Board of the International Monetary Fund (IMF) concluded the Article IV Consultation with France. ${ }^{1}$

\section{Background}

The French economy has produced a strong upturn, especially in comparison with other large euro-area countries. Initiated by a rebound in exports, domestic demand has become the driver of growth, thanks to supportive policies and a favorable starting position. Savings rates were unusually high, balance sheet problems in the corporate sector were confined to a small number of large firms, the financial sector was profitable, and the housing market was robust. The strength of private consumption reflects both fundamental and exceptional factors: implementation of key social security reforms diminished uncertainty, prospects for growth and inflation improved, and incomes of the cash constrained were supported. Fiscal measures were implemented to help sustain the momentum in household spending. Fixed investment had been weaker than usual during the downturn, with replacement investment being postponed, but after a period of deleveraging and widening profit margins, business investment rebounded. Residential construction strengthened, reflecting several years of rising house prices. However, with higher oil prices and some softening of the external environment, the staff expects real GDP growth to slow from 2.5 percent in 2004 to 2.2 percent in 2005, while official forecasts foresee continuing growth at 2.5 percent. Headline inflation, which reached

\footnotetext{
${ }^{1}$ Under Article IV of the IMF's Articles of Agreement, the IMF holds bilateral discussions with members, usually every year. A staff team visits the country, collects economic and financial information, and discusses with officials the country's economic developments and policies. On return to headquarters, the staff prepares a report, which forms the basis for discussion by the Executive Board. At the conclusion of the discussion, the Managing Director, as Chairman of the Board, summarizes the views of Executive Directors, and this summary is transmitted to the country's authorities. This PIN summarizes the views of the Executive Board as expressed during the Executive Board discussion based on the staff report.
} 
2.2 percent in September, is seen to remain persistent, slowly moderating in the course of 2005 . It will continue to reflect special factors-base effects from the tobacco tax increase, changes in regulated prices, oil price volatility, and the price cut agreed by large distributors. Long-term growth is being fettered by adverse demographics and structural weaknesses, a high tax and regulatory burden and, despite its increase in the 1990s, a low degree of labor utilization.

The 2005 draft budget targets a reduction in the general government deficit to 2.9 percent of GDP continuing the decline from 3.6 percent of GDP in 2004 and a peak of 4.1 percent of GDP in 2003. Following a structural improvement of about 0.5 percentage point of GDP in 2004, achieved through expenditure restraint at the central government level, the staff estimates the structural balance to improve by 0.2 percentage point of GDP in 2005 (excluding the transfer of the electricity utility's pension fund, equivalent to 0.4 percentage point of GDP). Central government expenditure is set to remain constant in real terms, but spending growth in other areas is relatively high. The net tax burden rises marginally because the increase in contributions related to the health care reform is not fully offset by a variety of smaller tax cuts in other areas. The size of the civil service is set to decline, as about 12 percent of retiring civil servants will not be replaced. For 2006-08, the authorities plan a steady reduction in the structural deficit by one-half of a percentage point per year on average, to reach a level of just below 1 percent of GDP by the end of the period. The health care reform is assumed to achieve a durable deceleration of annual nominal spending growth to 3.6 percent during $2006-08$, and the volume of overall spending is targeted to increase by 1.2 percent per year on average.

On structural issues, a health care reform has established the key instruments to gain control over the system's budget, with adjustable parameters to influence its revenues as well as the behavior of patients, providers, and insurance agencies. Ongoing civil service reform and decentralization are providing the opportunity to realize efficiency gains and tailor public services better to local needs. In product markets, the statutes of the public electricity and gas companies have been changed, opening the door for private investment; the authorities intend to accelerate divestiture from commercial activities as market conditions permit; and steps are being taken to accelerate the transposition of EU internal market and competition directives. In labor markets, cuts in social security contributions are set to continue to mitigate the impact of rising minimum wages stemming from the implementation of the 35-hour workweek; social partners have been allowed to negotiate derogations from the workweek regulations, including at the enterprise level; and the earned income tax credit has been raised. Other possible changes to labor market institutions-notably as regards employment protection--have for now been left to negotiations among the social partners. A "social cohesion" program has been adopted to bring people back to the labor market, relying on fiscal incentives and closer administrative follow-up of unemployed and benefit recipients, as well as public sector employment schemes.

The Financial System Stability Assessment conducted by IMF staff this year found no immediate systemic financial sector risk and confirmed the high quality of oversight and prudential supervision of the financial sector. It recommended a further strengthening of supervision through enhanced coordination and vigilance on banks' risk exposure. 


\section{Executive Board Assessment}

Executive Directors congratulated the French authorities for their skillful pursuit of reform policies, which have fostered confidence and supported an early and robust economic recovery. They welcomed the resumption of structural fiscal adjustment in 2004. Pension and health care reforms have improved the long-term fiscal outlook against the background of the impending demographic shock, while ongoing reforms in product markets are likely to boost growth. Directors urged the authorities to build on the strong performance by strengthening structural reforms and stepping up fiscal consolidation to secure higher long-term growth and fiscal sustainability. A key challenge will be to improve labor market institutions to raise labor utilization, while reducing the reliance of employment policies on budgetary resources.

Directors observed that the recent economic recovery has been driven by domestic demand. Downside risks exist on the external front. Although the pace of growth is likely to slow in 2005, mainly as a result of higher oil prices, France's economic outlook remains comparatively favorable. With monetary conditions likely to remain quite accommodative from France's perspective, stronger fiscal consolidation is unlikely to threaten the recovery.

In this setting, Directors urged the authorities to proceed decisively with fiscal adjustment. They saw a need to strengthen adjustment in 2005 compared to current budget plans, given France's weak underlying budgetary position and rising public debt. They noted that recourse to a pension fund transfer from the electricity utility would be a one-off measure, and not a durable fiscal adjustment. Directors considered that the alternative of genuine structural adjustment through reinforced expenditure restraint is feasible, inter alia through advancing and strengthening health care reform measures and reducing the large size of public employment by making more decisive use of the opportunity provided by the ongoing wave of retirements.

Directors considered that the intended cumulative fiscal consolidation by 2008 is broadly appropriate. It should be complemented by the early implementation of comprehensive growthenhancing reforms to secure long-run fiscal sustainability. In the absence of concrete measures in this direction, Directors felt that credibility would require stronger up-front and sustained adjustment until a small underlying surplus is achieved.

Directors stressed that early fiscal adjustment and growth-enhancing structural reforms will be essential to create room for a much-needed reduction in France's high tax burden. In the meantime, consideration should be given to changes in the tax structure to yield efficiency gains and remove distortions, especially those on capital and labor. Some Directors questioned the increased recourse to tax exemptions, with doubtful economic benefits, in the 2005 draft budget.

To ensure successful consolidation, Directors encouraged the authorities to continue strengthening France's fiscal framework. They welcomed the ongoing implementation of the output-oriented budget law and the efforts to address an ingrained spending culture at the central government level. They recommended the extension of this approach to social security and local authorities, where spending control has proven more difficult. Directors saw merit in setting multi-year limits on the level of general government spending. A few considered that 
establishing an independent agency to conduct forward-looking budget assessments would be useful. Directors stressed that preserving cyclical revenue windfalls will be crucial for fiscal consolidation and considered that the envisaged rule governing the ex ante allocation of such windfalls should allow for full play of automatic stabilizers to avoid structural slippages.

Directors emphasized the need for further efforts to reorient labor market policies, in order to move away from the current heavy reliance on budgetary measures. These measures had been instituted to mitigate the adverse consequences on labor costs and employment of high and rising minimum wages, the mandatory 35-hour workweek, and high marginal tax and benefit replacement rates. Directors stressed the need for comprehensive reforms of employment protection and benefits to sharpen incentives to work. They viewed the ongoing initiatives to tighten job-search requirements and reduce the duration of unemployment benefits as steps in the right direction. They called for further efforts to refocus entitlement systems toward moving people into market jobs. Other steps in this direction could include reducing the role of the judiciary in layoffs, ensuring greater flexibility in workweek regulations, and slowing the real increases in minimum wages and benefits, which have had the effect of excluding a large number of potential workers from activity. A number of Directors questioned the role assigned to public sector jobs in the new "social cohesion" program, while a few Directors felt that the program could help reconnect people with the labor force and reduce structural unemployment. Directors suggested that the cost effectiveness of this program be monitored closely. Directors welcomed the report of the Camdessus Commission, which makes far-reaching recommendations to enhance France's growth potential and reduce unemployment.

In product markets, Directors welcomed ongoing efforts to lighten the regulatory burden, simplify administrative procedures, and promote divestiture of commercial activities. They valued the change in the statutes of the electricity and gas utilities, which has introduced the possibility of private capital participation. Directors looked forward to the pending reform of corporate bankruptcy legislation. Directors believed that the attractiveness of France for investors is best defended by reforms in the goods and labor markets and steps to strengthen competition, rather than by an emphasis on "national champions."

Directors noted that the French financial sector has increased its resilience with the economic upturn. They welcomed the findings of the Financial Sector Stability Assessment, which has confirmed the high quality of oversight and prudential supervision. They recommended continued vigilance with respect to banks' potentially risky expansions, intensified cooperation among supervisory agencies, improved price transparency in financial services, and enhanced competition in the financial sector. Directors also encouraged the authorities to phase out remaining administrative interventions in the financial system, so as to improve resource allocation and monetary transmission. Directors welcomed France's leadership role and ongoing efforts to apply international standards against money laundering and the financing of terrorism and looked forward to the implementation of further reforms to strengthen this framework.

Directors commended France's contribution to official development assistance and looked forward to a further increase toward the U.N. target level. They encouraged France to promote efforts to bring the Doha round to a successful conclusion, in particular by supporting comprehensive liberalization of agricultural markets. Several Directors felt that moving forward 


\section{$-5-$}

the national implementation of the June 2003 reform of the Common Agricultural Policy would be helpful in this respect.

Public Information Notices (PINs) form part of the IMF's efforts to promote transparency of the IMF's views and analysis of economic developments and policies. With the consent of the country (or countries) concerned, PINs are issued after Executive Board discussions of Article IV consultations with member countries, of its surveillance of developments at the regional level, of post-program monitoring, and of ex post assessments of member countries with longer-term program engagements. PINs are also issued after Executive Board discussions of general policy matters, unless otherwise decided by the Executive Board in a particular case. The Staff Report for the 2004 Article IV Consultation with France is also available. 
France: Selected Economic and Social Indicators

(Annual percentage change; unless otherwise indicated)

\begin{tabular}{|c|c|c|c|c|c|}
\hline & 2000 & 2001 & 2002 & 2003 & $20041 /$ \\
\hline \multicolumn{6}{|l|}{ Real economy (change in percent) } \\
\hline Real GDP & 4.2 & 2.1 & 1.1 & 0.5 & 2.5 \\
\hline Domestic demand & 4.5 & 2.0 & 1.5 & 1.4 & 3.5 \\
\hline CPI (year average) & 1.8 & 1.8 & 1.9 & 2.2 & 2.4 \\
\hline Unemployment rate (in percent) & 9.3 & 8.5 & 8.9 & 9.4 & 9.5 \\
\hline Gross national savings (percent of GDP) & 22.4 & 22.1 & 20.6 & 19.3 & 19.1 \\
\hline Gross domestic investment (percent of GDP) & 21.0 & 20.4 & 19.6 & 19.0 & 19.9 \\
\hline \multicolumn{6}{|l|}{ Public finance (percent of GDP) 2/ } \\
\hline Central government balance & -2.5 & -2.3 & -3.9 & -4.0 & -3.2 \\
\hline General government balance & -1.4 & -1.6 & -3.3 & -4.1 & -3.6 \\
\hline General government gross debt & 57.1 & 56.8 & 58.7 & 63.7 & 64.7 \\
\hline \multicolumn{6}{|l|}{ Money and interest rates } \\
\hline M3 (end of year, percent change) 3/ & 4.3 & 10.9 & 6.6 & 6.4 & $\ldots$ \\
\hline Money market rate (in percent) 4/ & 4.4 & 4.3 & 3.3 & 2.3 & 2.1 \\
\hline Government bond yield (in percent) $5 /$ & 5.5 & 5.0 & 4.9 & 4.2 & 4.2 \\
\hline \multicolumn{6}{|l|}{ Balance of payments (percent of GDP) } \\
\hline Trade balance & -0.3 & 0.3 & 0.5 & 0.1 & -1.0 \\
\hline Current account & 1.4 & 1.6 & 1.0 & 0.3 & -0.8 \\
\hline Official reserves (US\$ billion) 6/ & 37.0 & 31.7 & 28.4 & 30.2 & 30.6 \\
\hline \multicolumn{6}{|l|}{ Fund position (as of August 31,2004 ) } \\
\hline Holdings of currency (percent of quota) & & & & & 64.3 \\
\hline Holdings of SDRs (percent of allocation) & & & & & 50.9 \\
\hline Quota (SDRs million) & & & & & $10,738.5$ \\
\hline \multicolumn{6}{|l|}{ Exchange rates } \\
\hline Exchange rate regime & \multicolumn{5}{|c|}{ Participant in EMU } \\
\hline Euro per U.S. dollar (October 13, 2004) & & & & & 1.23 \\
\hline Nominal effective rate $(2000=100) 7 /$ & 100.0 & 100.4 & 101.2 & 104.7 & 105.3 \\
\hline Real effective exchange rate $(2000=100) 7 / 8 /$ & 100.0 & 98.9 & 99.7 & 102.6 & 102.7 \\
\hline
\end{tabular}

Sources: Data provided by the authorities; and Fund staff estimates.

$1 /$ Staff projections.

2/ Data for 2001-02 exclude the proceeds from the sale of UMTS licenses, which amount to about 0.1 percent of GDP.

3/ Data are for the euro area (starting in 1999).

4/ Data refer to the interbank rate (as from 1999 onwards). For 2004, data are as of August.

5/ Average yield to maturity on public sector bonds with original maturities of more than five years.

The figure for 2004 refers to August.

6/ Excluding gold, end-of-period; from 1999, eurosystem definition. The figure for 2004 refers to August.

7/ The figure for 2004 refers to August.

8 / Based on relative normalized unit labor costs in manufacturing. 